\title{
Invasive bees and their impact on agriculture
}

\author{
Marcelo A. Aizen ${ }^{\mathrm{a}, *}$, Marina P. Arbetman ${ }^{\mathrm{a}}$, Natacha P. Chacoff ${ }^{\mathrm{b}, \mathrm{c}}$, \\ Vanina R. Chalcoff ${ }^{a}$, Peter Feinsinger ${ }^{d}$, Lucas A. Garibaldi ${ }^{e, f}$, \\ Lawrence D. Harder ${ }^{\mathrm{g}}$, Carolina L. Morales ${ }^{\mathrm{a}}$, Agustín Sáez ${ }^{\mathrm{a}}$, and \\ Adam J. Vanbergen ${ }^{\mathrm{h}}$ \\ ${ }^{a}$ Instituto de Investigaciones en Biodiversidad y Medioambiente (INIBIOMA), Universidad Nacional del \\ Comahue-CONICET, San Carlos de Bariloche, Rio Negro, Argentina \\ ${ }^{\mathrm{b}}$ Instituto de Ecología Regional (IER), CONICET-Universidad Nacional de Tucumán, San Miguel de \\ Tucumán, Tucumán, Argentina \\ ${ }^{c}$ Facultad de Ciencias Naturales e Instituto Miguel Lillo, Universidad Nacional de Tucumán, San Miguel de \\ Tucumán, Argentina \\ ${ }^{\mathrm{d} C e n t r o}$ de Estudio y Aplicación del Ciclo de Indagación, Facultad de Ciencias Naturales e Instituto Miguel \\ Lillo, Universidad Nacional de Tucumán, San Miguel de Tucumán, Argentina \\ ${ }^{\text {e} U n i v e r s i d a d ~ N a c i o n a l ~ d e ~ R i ́ o ~ N e g r o, ~ I n s t i t u t o ~ d e ~ I n v e s t i g a c i o n e s ~ e n ~ R e c u r s o s ~ N a t u r a l e s, ~}$ \\ Agroecología y Desarrollo Rural, San Carlos de Bariloche, Río Negro, Argentina \\ ${ }^{\mathrm{f}}$ Consejo Nacional de Investigaciones Científicas y Técnicas, Instituto de Investigaciones en Recursos \\ Naturales, Agroecología y Desarrollo Rural, San Carlos de Bariloche, Río Negro, Argentina \\ ${ }^{g}$ Department of Biological Sciences, University of Calgary, Calgary, AB, Canada \\ ${ }^{\mathrm{h}}$ Agroécologie, AgroSup Dijon, INRAE, Université de Bourgogne Franche-Comté, Dijon, France \\ *Corresponding author: e-mail address: maizen@comahue-conicet.gob.ar
}

\section{Contents}

1. Introduction 50

2. Plant-pollinator interaction as a benefit-cost relation 53

2.1 Direct costs 54

2.2 Indirect costs 57

3. Invasive bees 59

$\begin{array}{ll}\text { 3.1 The western honey bee } & 60\end{array}$

3.2 Bumble bees 61

3.3 Other bees 62

4. Drivers of bee invasion success 62

4.1 Bee introductions and trade 63

4.2 Ecological opportunities and displacement of native bees 65

$\begin{array}{ll}4.3 \text { Anthropogenic disturbance } & 67\end{array}$

5. Consequences of bee invasions for crop pollination 68

5.1 Interaction of alien bees with crop flowers 69

$\begin{array}{ll}5.2 \text { Visit frequencies of alien bees } & 71\end{array}$

5.3 Benefit-cost relations of interacting with alien bees 73

5.4 Case study 1: Bumble-bee invasion and raspberries 74

5.5 Case study 2: Coffee and the African honey bee in the Americas, revisited 76 
6. The future of agriculture in a context of bee invasions

79

Acknowledgements

81

References

\section{Abstract}

Increasing honey demand and global coverage of pollinator-dependent crops within the context of global pollinator declines have accelerated international trade in managed bees. Bee introductions into agricultural landscapes outside their native ranges have triggered noteworthy invasions, especially of the African honey bee in the Americas and the European bumble bee Bombus terrestris in southern South America, New Zealand, Tasmania, and Japan. Such invasions have displaced native bees via competition, pathogen transmission, and invaders' capacity to exploit anthropogenic landscapes. At high abundance, invasive bees can degrade the mutualistic nature of many of the flower-pollinator interactions they usurp, either directly by affecting flower performance or indirectly by reducing the pollination effectiveness of other flower visitors, with negative consequences for crop pollination and yield. We illustrate such effects with empirical examples, focusing particularly on interactions in the Americas between $B$. terrestris and raspberry and between the African honey bee and coffee. Despite high bee abundance and flower visitation in crops, theoretical and empirical evidence suggests that agricultural landscapes of pollinator-dependent crops dominated by invasive bees will be less productive than landscapes with more diverse pollinator assemblages. Safeguarding future crop yield and aiding the transition to more sustainable agricultural landscapes and practices require we address this impact of invasive bees. Actions include tighter regulation of the trade in bees to discourage further invasions, reducing invasive bee densities and dominance, and active enhancement of ecological infrastructure from field to landscape scales to promote wild bee abundance and diversity for sustained delivery of crop pollination services.

\section{Introduction}

Interaction between human activities and natural ecosystem processes increasingly determines the characteristics of contemporary landscapes. In particular, food production by conventional intensive agriculture (Vanbergen et al., 2020) is a major modifier of global landscapes (IPBES, 2019). This activity involves land transformation through industrial-scale management of livestock and crop monocultures with large external inputs and mechanization (KovácsHostyánszki et al., 2017; Pretty, 2018). The widespread adoption of this model of food production has simplified agroecosystems by homogenizing landscape structure, biotic composition, and ecosystem functioning (Dainese et al., 2019; IPBES, 2019; Kovács-Hostyánszki et al., 2017; Potts et al., 
2016; Rusch et al., 2016). As one example, agricultural intensification negatively affects native pollinators (Vanbergen and The Insect Pollinators Initiative, 2013), diverse animals that provide substantial benefits to humans through a web of interactions with other organisms, especially by providing pollination services to crops (Potts et al., 2016).

Paradoxically, global agriculture increasingly depends on pollinators, owing to greatly intensified cultivation of fruit and seed crops for which animal pollination enhances yield (Aizen and Harder, 2009). The percentage of agricultural land planted with pollinator-dependent crops grew worldwide from $19.4 \%$ in the early 1960 s to $32.8 \%$ by 2016 (Aizen et al., 2019a). This increase largely reflects a $30 \%$ expansion of the global area of agricultural land, mostly dedicated to crops that depend on pollinators (Aizen and Harder, 2009; Aizen et al., 2008a; Garibaldi et al., 2011a), especially transgenic oil-seed crops grown in monocultures (e.g. soybean, canola, and oil palm) and a diversity of temperate and tropical fruit crops (Aizen et al., 2019a). The spread of pollinator-dependent crops correspondingly increases the need for the ecological services provided by wild and domesticated pollinators (Aizen and Harder, 2009), primarily but not exclusively bees (Rader et al., 2016), to maximize yield (Potts et al., 2010).

Just as demands for crop pollination are rising, one consequence of this agricultural expansion and intensification has been the severe depletion of nesting and floral resources (Baude et al., 2016; Biesmeijer et al., 2006; Scheper et al., 2014) that support the health and survival of wild pollinator populations (Goulson et al., 2015; Kennedy et al., 2013; Potts et al., 2010, 2016; Vanbergen et al., 2018). Indeed, landscape simplification and homogenization, along with intensive use of pesticides associated with large-scale agriculture, are among the leading causes of a worldwide pollinator decline (Brittain et al., 2010; Potts et al., 2010; Vanbergen and The Insect Pollinators Initiative, 2013; Zattara and Aizen, 2019). Such effects compromise agricultural productivity because visitation by wild bees enhances yield in most pollinator-dependent crops (Brittain et al., 2013a; Garibaldi et al., 2013; Potts et al., 2016; Rader et al., 2016). As a consequence, agriculture increasingly relies on pollination by "domesticated" or "managed" bees (IPBES, 2016; Klein et al., 2007; Morse and Calderone, 2003; Pitts-Singer and Cane, 2011). Historically, the western honey bee (Apis mellifera) was the managed bee of choice, and it remains so for many crops. However, honey bees pollinate some crops poorly (e.g. alfalfa, tomato, peppers) and cannot be used effectively in confined conditions such as greenhouses (Bosch and Kemp, 2002; Velthius and van Doorn, 2006). Therefore, methods have 
been developed for large-scale rearing and maintenance of other bees, especially bumble bees (Bombus spp.) and some solitary bees (e.g. Megachile rotundata, Osmia spp.).

These agricultural trends along with increasing demand for honey by a growing human population (Aizen and Harder, 2009) have greatly boosted worldwide trade in bees (IPBES, 2016), accelerating the transport of bees within and well beyond their native ranges. Some bees, notably A. mellifera and Bombus terrestris, subsequently became invasive: dispersing, surviving at high abundance, and reproducing in a wide range of habitats far beyond their introduction sites (Morales et al., 2017). Even though bee trade may bring short-term benefits, these invading species have had diverse long-lasting negative effects, including impacts on the abundance and composition of native pollinator assemblages from local to continental scales (Aizen and Feinsinger, 1994a; Bommarco et al., 2012; Chacoff and Aizen, 2006; Goulson, 2003; Herrera, 2020; Mallinger et al., 2017; Morales et al., 2013; Zattara and Aizen, 2019). Given that 88\% of angiosperm species are animal-pollinated (Ollerton et al., 2011) and seed production of over 70\% of crop species benefits from animal pollination (Klein et al., 2007), especially by wild bees (Garibaldi et al., 2013), bee invasions pose considerable risks for populations of wild and crop plants (Potts et al., 2016).

Here, we describe and anticipate the possible impacts of invasive bees on plant reproduction (seed set and fruit production), with emphasis on yield in pollinator-dependent crop species. Although these bees can enhance crop production when either properly managed or in agricultural landscapes devoid of alternative pollinators, we propose that they can pose a hazard for both native biotas and agriculture when they become too abundant or dominant.

To set the context, we first outline a benefit-cost model of how high abundance of invasive bees can alter original plant-pollinator interactions, affecting seed and fruit output (Aizen et al., 2008b; Morales et al., 2017; Morris et al., 2010). We then review the principal invasions precipitated by growing worldwide trade in bees, focusing on the relatively recent, geographically extensive invasions of an African subspecies of the western honey bee (A. m. scutellata) and the European buff-tailed bumble bee (B. terrestris) of the Americas (Morales et al., 2017). Although bee trade initiated these invasions, we also discuss the role of local conditions that facilitated establishment and range expansion of these bees once introduced, including the existence of ecological opportunities-perhaps resulting from the displacement of native bees-and anthropogenic habitat disturbance. 
Together, the conceptual framework, historical accounts of invasions, and understanding of local drivers of invasion reveal scenarios of impacts of introduced bees on crop yield.

We then explore these impacts from several perspectives. First, we review the importance of $A$. mellifera and $B$. terrestris as agricultural pollinators in terms of the number of crops they pollinate. Next, we examine the abundance and visitation frequency of these species when they become invasive, as the benefit-cost model predicts reduced crop yield when invasive species become too abundant or visit too excessively. Finally, we assess evidence for decreases in seed production and crop yield arising from increasing interaction costs at high visitation frequency. We specifically use the benefit-cost model to interpret two case studies involving reduced fruit quality in commercial raspberry fields affected by the invasion of southern South America by B. terrestris and Roubik's (2002) proposal that invasion of the Neotropics by African honey bees improved coffee yield by increasing pollination stability.

We close by discussing the future of agricultural landscapes within the context of bee invasions. We argue that the principles revealed by bee invasions apply also to the consequences of increasing simplification of bee assemblages and their domination by a few species caused by anthropogenic disturbance, in general, and intensive agriculture, in particular.

\section{Plant-pollinator interaction as a benefit-cost relation}

Most animal pollinators inadvertently transport pollen within and among plants while foraging for resources or searching for other opportunities that flowers provide. Plants benefit from this interaction to the extent that conspecific dispersal improves siring success and fruit and seed production. Most flower-visiting animals benefit from available food, especially sugar in nectar and/or protein in pollen, but also oils, developing seeds, and "food bodies" (Simpson and Neff, 1981; Willmer, 2011). In some cases, flower visitors instead seek pheromone precursors, resins for nest construction, heat, shelter or mating sites. Costs associated with this interaction include the energy and resource investment in floral "rewards" and signals by plants (e.g. Andersson, 1999; Ashman and Schoen, 1994; Harder and Barrett, 1992), and the energy and time expended on searching numerous flowers for limited gain per flower by animals (e.g. Chittka and Spaethe, 2007; Schmid-Hempel et al., 1985) while increasing predation risk 
(e.g. Dukas and Morse, 2003). When gross benefits exceed costs for both partners, plants and pollinators, the result is mutualism, which is the prevalent characterization of the plant-pollinator interaction.

Because each partner in a mutualism acts in its own self-interest (i.e. maximizing individual net benefit), improved performance by one partner can increase costs for its counterpart (Bronstein, 2001). Indeed, under certain conditions a flower-animal interaction can instead be antagonistic (i.e. costs exceed benefits), such as deceitful pollination (Johnson and Schiestl, 2016), nectar robbing (Irwin et al., 2010) or pollen theft (Hargreaves et al., 2009). One such condition is extreme abundance of one of the partners relative to the other, which can increase interaction costs via excessive interaction frequency (Morris et al., 2010), as often observed in plant-pollinator interactions involving invasive bees (Aizen et al., 2014; Morales et al., 2017). Interaction costs can arise either from direct interaction of the partner species or indirectly as mediated by a third mutualistic species, for instance a second pollinator (Fig. 1). From a plant's perspective, these density-dependent direct and indirect interaction costs are most relevant to the impact of invasive bees on seed production and, by extension, to their impact on crop yields in future landscapes.

\subsection{Direct costs}

Interactions of animals with flowers can impose diverse direct costs on plant reproduction (Table 1). These costs, such as nectar robbing and flower damage, can accumulate as individual flowers receive more visits (Aizen et al., 2014; Morris et al., 2010), as influenced by pollinator abundance (Garibaldi et al., 2020). Extreme pollinator abundance, such as that observed for some invasive bees or in fields stocked with managed bees at high densities (Garibaldi et al., 2020; Sáez et al., 2014), can translate into uncommonly frequent pollinator visits per flower, exacerbating costs (Fig. 1A).

Aggravated direct interaction costs to plants as pollinator abundance increases can cause a shift from mutualism to antagonism (Fig. 1A). The benefits of interaction, namely ovule fertilization leading to seed production and seed siring, generally increase with pollinator visitation when visits are infrequent. As visitation increases, however, seed production reaches an asymptote either because all ovules are fertilized or because insufficient resources are available to develop additional seeds. This female limit can be reached after only a few visits per flower, even though more visits might benefit pollen export (Bell and Cresswell, 1998; Carlson, 2007). 

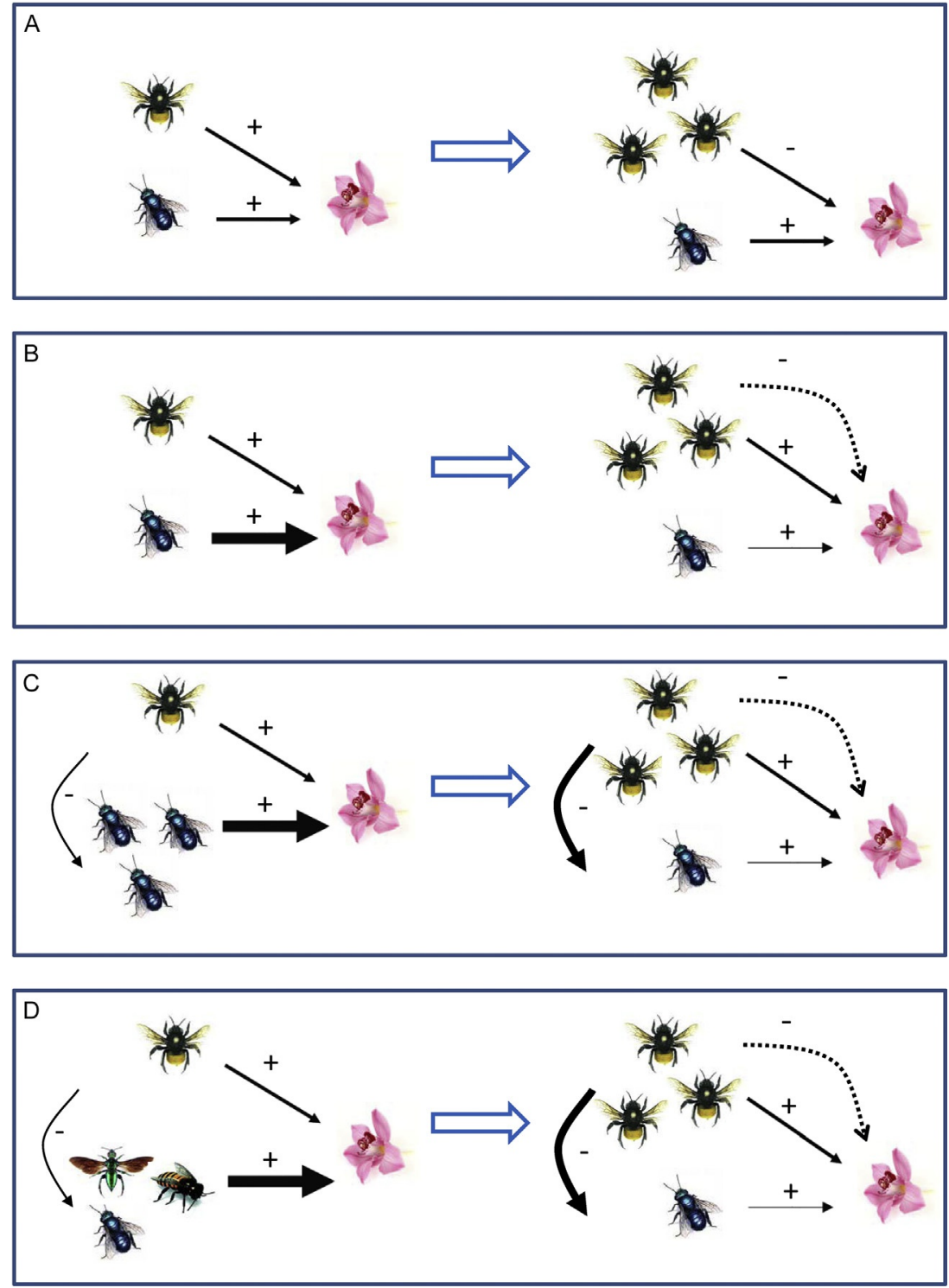

Fig. 1 Expected effects of increased abundance of an invasive bee species (bumble bee symbol) on benefits of pollinator interaction for plant reproduction when the invasive species imposes direct $(A)$ or indirect $(B-D)$ interaction costs. The left- and right-hand scenarios, respectively, illustrate the nature of interactions at low and high density of the invasive species, which are linked by a blue arrow. For each scenario, the sign above a black arrow indicates the qualitative interaction effect and arrow width represents the quantitative effect. Solid and dotted arrows depict direct and indirect effects, respectively. Panel (A) illustrates a shift from high to low benefit-cost ratios for the plant associated with aggravated direct interaction costs as invader density increases. Panels (B-D) show three means by which indirect effects of intensified competition between invading and native bees could weaken mutualistic benefits for the plant, including: (B) decreased per-visit pollination effectiveness of native pollinators; (C) replacement of effective native pollinators by less effective alien pollinators; or (D) decreased diversity of native pollinators. 
Table 1 Direct interaction costs and their potential impacts.

\begin{tabular}{|c|c|c|}
\hline Cost & Potential impact & References \\
\hline $\begin{array}{l}\text { Nectar } \\
\text { replenishment }\end{array}$ & $\begin{array}{l}\text { Increased photosynthate expenditure } \\
\text { on nectar production }\end{array}$ & $\begin{array}{l}\text { Ordano and Ornelas } \\
\text { (2005) and Pyke (2016) }\end{array}$ \\
\hline Nectar robbing & $\begin{array}{l}\text { Increased pollination limitation of } \\
\text { seed production due to fewer visits } \\
\text { by legitimate pollinators }\end{array}$ & Irwin et al. (2010) \\
\hline Pollen theft & $\begin{array}{l}\text { Decreased pollen available for export } \\
\text { and import }\end{array}$ & Hargreaves et al. (2009) \\
\hline Flower damage & $\begin{array}{l}\text { Decreased flower attractiveness when } \\
\text { the corolla is damaged, decreased } \\
\text { ovule fertilization when the stigma } \\
\text { or style is broken, or decreased seed } \\
\text { development when the ovary is } \\
\text { injured }\end{array}$ & $\begin{array}{l}\text { Sáez et al. (2014) and } \\
\text { Traveset et al. (1998) }\end{array}$ \\
\hline $\begin{array}{l}\text { Stigmatic } \\
\text { pollen removal }\end{array}$ & Reduced stigmatic pollen load & $\begin{array}{l}\text { Gross and MacKay } \\
(1998), \text { Young (1988) } \\
\text { and Young and Young } \\
(1992)\end{array}$ \\
\hline $\begin{array}{l}\text { Increased } \\
\text { pollen tube } \\
\text { attrition }\end{array}$ & $\begin{array}{l}\text { Failure of pollen-tube populations in } \\
\text { overcrowded styles due to scramble } \\
\text { competition }\end{array}$ & Harder et al. (2016a,b) \\
\hline $\begin{array}{l}\text { Flower } \\
\text { infection by } \\
\text { pathogens }\end{array}$ & Sexual castration & $\begin{array}{l}\text { Jennersten (1988) and } \\
\text { Shykoff and Bucheli } \\
(1995)\end{array}$ \\
\hline $\begin{array}{l}\text { Nectar } \\
\text { infection by } \\
\text { bacteria and } \\
\text { yeasts }\end{array}$ & $\begin{array}{l}\text { Altered nectar composition deterring } \\
\text { further visitation }\end{array}$ & $\begin{array}{l}\text { Herrera et al. (2013), } \\
\text { Vannette et al. (2013) } \\
\text { and Vannette and } \\
\text { Fukami (2016) }\end{array}$ \\
\hline
\end{tabular}

Beyond this visit intensity, direct plant costs arising from increasing frequencies of animal visitation per flower can increase linearly or even accelerate (Aizen et al., 2014; Morris et al., 2010). As a result, net benefits, such as fruit production and production of seeds per fruit, should exhibit a hump-shaped relation to visit frequency (Fig. 2A) and could even reduce seed set below that resulting from autonomous self-pollination. Such a relation has been both predicted for raspberry fields invaded by $B$. terrestris in Patagonia based on saturation of pollination benefits accompanied by continually increasing 
A

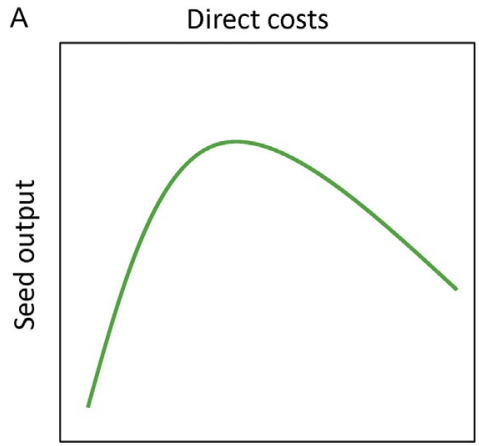

Visit frequency
B

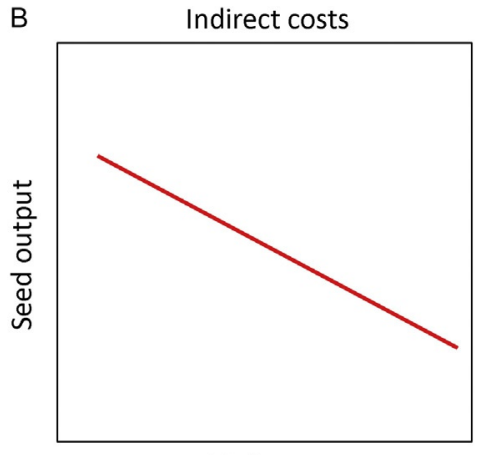

Visit frequency

Fig. 2 Predicted general relations of seed output to visitation frequency by an invasive bee species if increased invader density primarily exacerbates (A) direct interaction costs or (B) indirect costs.

flower damage costs (Sáez et al., 2018) and demonstrated in a meta-analysis of studies on crops subject to high visitation ( $\gg 10$ visits flower $^{-1}$ ) by managed honey bees (Rollin and Garibaldi, 2019; see Section 5).

Under most natural circumstances, plants influence the number of pollinator visits received by individual flowers through the genetic determination of floral lifespan and attractiveness (Ashman, 2004; Klinkhamer et al., 1993; Pyke, 2016) and plastic responses to actual visit frequency (Harder and Johnson, 2005; van Doorn, 1997). Extremely frequent visitation that damages flowers or leads to unusually large stigmatic pollen loads that promote massive pollen-tube abortion (Table 1) is rare in nature. As a consequence, a hump-shaped relation of plant reproductive output to visit frequency is likely uncommon and difficult to distinguish from a saturating relation under most natural situations, for which interaction costs do not typically exceed interaction benefits (Harder et al., 2016a,b). Nevertheless, adaptive regulation of pollinator visitation by different floral traits may fail when a pollinator becomes super-abundant, generating a hump-shaped relation. This consequence seems to arise when invasive bees reach locally high densities (Aizen et al., 2014).

\subsection{Indirect costs}

Massive invasions by alien pollinators can affect pollination by native pollinators indirectly through negative effects on the pollination efficiency/ effectiveness, abundance, and/or diversity of native species (Fig. 1B-D). 
Such effects could arise from competition between alien and native bees for floral resources or nest sites or from introduction of pathogens by invading bees (Goulson, 2003). In either case, seed production will decline with increasing visit frequency by the invader if reduced pollination by native pollinators is not offset by increased pollination by the invasive pollinator, raising the indirect cost of a plant's overall interaction with pollinators (Fig. 2B).

The quantity and quality of pollen deposited on a flower's stigma per visit varies widely among pollinators (Herrera, 1987, 1989). From the perspective of a plant's female function, deposition of compatible pollen per visit is a relevant measure of an animal's per visit pollination effectiveness, whereas the product of mean deposition of compatible pollen during individual visits and the frequency of visits is a relevant measure of overall pollination effectiveness (Willmer, 2011). Pollen deposition per visit by an effective pollinator and subsequent seed production can decline with increasing visit frequency of a less effective floral visitor (Fig. 1B). For example, bees that actively collect pollen to provision their larvae can greatly decrease pollen availability, so pollen transport to stigmas by another, otherwise effective pollinator can be reduced or even eliminated in the presence of pollen thieves (Chalcoff et al., 2012; Hargreaves et al., 2009, 2010). Likewise, by reducing the availability of reward a nectar robber can shorten visits by legitimate pollinators, reducing both pollen removal and deposition and possibly inducing otherwise legitimate pollinators to engage in secondary robbing (Irwin et al., 2010).

Given a constant total number of visits, displacement of an effective native pollinator by a less effective alien pollinator could reduce the total quantity or quality of pollen deposited on stigmas of a focal plant species (Dohzono and Yokoyama, 2010; Fig. 1C). Such displacement could arise from foraging responses, if native pollinators react to resource competition by shifting their attention to other plant species. For instance, increased visitation by an invasive nectar robber can render flowers unrewarding for a legitimate pollinator and decrease its visit frequency (Irwin and Brody, 1998). Invasive social bees, like the African honey bee, which tend to provide low-quality pollination by visiting sequentially several flowers per plant, can also reduce visitation by high-quality pollinators that move more pollen among plants (e.g. Aizen and Feinsinger, 1994a,b). Displacement can become permanent when competition or pathogen transmission depletes or extirpates populations of native pollinators (e.g. Arbetman et al., 2012; Morales et al., 2013).

Displacement of native pollinators by an invader will also generally reduce the species diversity of a plant's pollinators. Plants often benefit in 
various ways from interacting with a diverse pollinator assemblage. First, different pollinators can forage in different habitats or microhabitats where a plant species occurs and blooms, or be active at different periods of the day or flowering season, thus providing more stable and effective pollination service (Albrecht et al., 2012; Brittain et al., 2013a). Second, the probability of visitation by an effective pollinator species increases with pollinator diversity (Albrecht et al., 2012). This sampling effect is particularly relevant agriculturally because crops typically flower for short periods and flowering phenologies vary spatially and temporally (Bartomeus et al., 2013; Winfree et al., 2018). Last, antagonistic interactions between pollinator species can increase pollination quality. Interference or exploitation competition for floral resources can induce pollinators to fly farther between consecutive visits, promoting outcrossing (Brittain et al., 2013b; Greenleaf and Kremen, 2006). Combining all these influences, reduced diversity of a pollinator assemblage in the presence of a highly abundant, dominant, managed, or invasive pollinator can decrease both pollination quantity and quality (Fig. 1D).

\section{Invasive bees}

Range expansion occurs naturally during the histories of most species (Chuang and Peterson, 2016; Tomiolo and Ward, 2018). However, humanaided expansion often has a different character than this natural process, in part because it commonly involves establishing populations far beyond a species' native range (Blackburn et al., 2014; Hastings et al., 2005). The establishment success of these populations can be augmented by repeated human "seeding" (Simberloff, 2009) that rescues them from early extinction (Brown and Kodric-Brown, 1977). Many bee species have established outside their native ranges following accidental or intentional introductions (Goulson, 2003). For instance, cavity-nesting Anthidium manicatum was accidentally transported from Europe to North America along with its nesting material, whereas other cavity-nesting Megachile and Osmia have been transported intentionally in the same direction to improve pollination services (Gibbs and Sheffield, 2009). Several species introduced both accidentally and intentionally have established self-sustaining, expanding populations in the new regions to which they were transported (Aizen et al., 2019b; Geslin et al., 2017b; Goulson, 2003; Morales et al., 2017)—i.e. they became invasive (sensu Pyšek and Richardson, 2006). 


\subsection{The western honey bee}

The western honey bee, A. mellifera, is one of eleven Eurasian Apis species that are characterized by their perennial eusocial colonies (Engel, 1999). Its native range extends from northern Europe to southern Africa and from western Europe to the Ural Mountains and the Arabian Peninsula. More than 25 subspecies are recognized throughout its distribution (Schneider et al., 2004). For more than 4000 years, long before the pollination role of honey bees was appreciated, humans have managed this species as a source of honey, a derivative of floral nectar that colonies store to survive inclement periods (Crane and Graham, 1985). Because honey bee colonies can be maintained and moved easily in artificial containers, they have been transported from their native range to every continent except Antarctica (Moritz et al., 2005). During the 20th century, honey bees also became the species of choice for intentionally enhancing crop pollination (IPBES, 2016). In landscapes permitting year-round survival, honey bee swarms from managed colonies often establish feral colonies and become self-sustaining components of the local bee (and pollinator) fauna (Hung et al., 2018), often with detrimental consequences for native species (Mallinger et al., 2017).

Apis mellifera ligustica is the most widespread managed honey-bee subspecies, but it performs poorly under tropical conditions (Ruttner, 1988), which motivated the search for other subspecies to enhance honey production in tropical countries. In 1956, queens of the African subspecies A. m. scutellata were imported to Sao Paulo State, Brazil, to hybridize with $A$. m. ligustica (Moritz et al., 2005). The subsequent accidental release of 26 swarms of African honey bees in 1957 started the most extensive bee invasion to date. By the mid-1970s the American range of this bee extended throughout most of the central and eastern Amazonian Basin and south to central Argentina. African honey bees were first observed in Central America during 1982, reached Mexico in 1985 and arrived in the southern USA during the 1990s (Moritz et al., 2005). The current range of the African honey bee in the Western Hemisphere covers $>15,000,000 \mathrm{~km}^{2}$, including most of South and Central America and southern states of the USA. Throughout its range, the African honey bee has remained largely distinct genetically from other European honey bee subspecies (Schneider et al., 2004; Smith, 1991). Given this limited hybridization and introgression, we refer to this invasive bee as African, rather than Africanized as in some other accounts of this invasion (Morales et al., 2017). 


\subsection{Bumble bees}

Bumble bees, Bombus spp., comprise about 260 eusocial species of large bees (Williams, 1998). They are mostly cold-adapted and, unlike honey bees, their colonies are annual, except for those of a few tropical species, like B. pauloensis (Sakagami, 1976). Eurasia has the most diverse Bombus fauna, followed by North America and South America (Williams, 1998). No native bumble bees occur in Oceania or Africa south of the Mediterranean coast. Bumble bees are important pollinators of many crops, especially those requiring active vibration of the anthers to release pollen (buzz-pollination), under field and greenhouse conditions (Velthius and van Doorn, 2006). Methods have been developed for rearing and transporting several bumble bee species. Two species in particular, the European B. terrestris and the North American B. impatiens, are reared at industrial scales for managed pollination (Reade et al., 2015). Although one-third of Bombus species are declining, some species, particularly those that are managed, are thriving (Arbetman et al., 2017).

Bumble bee species have been translocated globally for agricultural pollination. Four species, B. hortorum, B. terrestris, B. subterraneus and B. ruderatus, were first introduced and established in New Zealand from the UK more than a century ago (Howlett and Donovan, 2010; Macfarlane and Gurr, 1995). About 300 queens of long-tongued B. ruderatus were shipped from New Zealand to Chile during the early 1980s (Arretz and Macfarlane, 1986). Short-tongued B. terrestris has been introduced from Europe to Israel, northern Africa, Asia, Central America and Chile, and secondarily from New Zealand to Japan and Tasmania (Goulson, 2003; Montalva et al., 2011). Some of these introductions resulted in extensive invasions (Aizen et al., 2019b). Bombus ruderatus became invasive in southern South America and its range now extends along both sides of the Andes to more than $400 \mathrm{~km}$ south of the original introduction sites in south-central Chile (Morales et al., 2013). This invasion was eclipsed by that of $B$. terrestris, which has invaded every region into which it has been introduced, including New Zealand, Tasmania, Japan, and South America. This remarkable invasive potential is most evident in South America. Since 1997, B. terrestris has expanded its South American range more than $2000 \mathrm{~km}$ southward from the original introduction sites in central Chile, to the southernmost islands of the continent (Cape Horn, south of Tierra del Fuego), and from the Pacific to the Atlantic coasts of Patagonia (Aizen et al., 2019b). Abiotic niche models predict further range expansion by $B$. terrestris northward to southern Perú, Bolivia and Brazil, and across the Argentine Pampas (Acosta et al., 2016). 


\subsection{Other bees}

Several species of solitary bees, mostly Megachilidae, have been intentionally introduced beyond their native ranges for pollination, largely owing to their capacity to trigger the explosive release of the concealed stamens and pistil of alfalfa flowers, which is required for pollination. The most extensive introduction involves the European Megachile rotundata, introduced in large numbers to South and North America for alfalfa pollination and now reared and traded extensively in the USA and Canada (Pitts-Singer and Cane, 2011). Several Osmia species have also been introduced to the Americas from Europe and Asia to pollinate temperate fruit crops. Osmia cornuta was introduced to California from Spain for almond pollination, whereas O. cornifrons was introduced to the east coast of the USA from Japan for apple pollination (Goulson, 2003, and references therein). Osmia species have also been introduced to non-native regions within countries. For example, O. ribifloris biedermannii was introduced from the west to the east coast of the USA for blueberry pollination (Stubbs et al., 1994). A halictid example involves Nomia melanderi, which was introduced in New Zealand from North America during the early 1970s for alfalfa pollination (Howlett and Donovan, 2010). Although some introduced solitary bees have established self-sustaining feral populations and even expanded their geographical ranges (Goulson, 2003), they do not appear to have dominated native pollinator communities or have had noteworthy effects on the native bee fauna in the invaded ranges (see Table 2.4.3 in IPBES, 2016). For instance, the long-term decline of native O. lignaria in eastern North America appears to have been unrelated to the introduction and range expansion of its alien congeneric O. cornifrons in the late 1970s (Centrella, 2019). Although these examples suggest that introduced solitary bees have limited effect on native bee faunas, this remains to be assessed by targeted impact assessment.

\section{Drivers of bee invasion success}

Whether humans are involved or not, species invasions, including bee invasions, encompass three principal processes: arrival of a species to a novel geographical area, initial establishment, and subsequent spread (Davis, 2009). Species sometimes disperse long distances without human aid, such as crossing oceans by drifting on air or water currents or by arriving on dispersal agents such as migratory birds (Nathan et al., 2008; Nogales et al., 2012). Once a species reaches a new location, among other factors, 
its fate depends on whether the local environment permits establishment, as determined by abiotic suitability, the relative abundance of facilitating species and the relative rarity of competitors and enemies (Davis, 2009). If these conditions exist, newly arrived species may also displace species occupying similar niches (Catford et al., 2018). Once established, the species' subsequent spread depends on dispersal ability and increased propagule pressure provided by local production and external input of dispersing individuals (Davis, 2009; Simberloff, 2009). Humans contribute to all aspects and stages of species invasion by inadvertently or intentionally transporting thousands of species, often repeatedly, to new ranges (Jeschke and Strayer, 2005; Meyerson and Mooney, 2007), and by creating conditions favourable to their establishment and population growth through habitat degradation and suppression of competitors or enemies (Davis, 2009; Lodge, 1993; Shea and Chesson, 2002). Therefore, trade, ecological opportunities and displacement of native counterparts, and anthropogenic disturbance have probably all facilitated bee invasions.

\subsection{Bee introductions and trade}

Bee introduction, a necessary but not sufficient condition for the occurrence of a bee invasion, has become increasingly frequent and extensive in recent years. In addition to the multiple unintended or intended introductions of small numbers of individual bees (e.g. bumble bees in New Zealand, Howlett and Donovan, 2010; African honey bees in Brazil, Moritz et al., 2005), millions of bees have been produced and traded within and among continents since the 1980s (Aizen et al., 2019b; Armitage, 2018; Owen, 2017; Velthius and van Doorn, 2006). This burgeoning international bee trade is both economically profitable and a major threat to biodiversity (Sutherland et al., 2017). Most recent trade in bees involves A. mellifera reared in Australia (Armitage, 2018) and B. terrestris reared in Europe and Israel (Aizen et al., 2019b). Also reared commercially are other bumble bee species, such as B. impatiens in eastern North America, B. ignitus in Japan, and more recently B. pauloensis in South America, as well as several species of alkali, mason and leaf-cutter bees. Apart from Megachile rotundata and to a lesser extent a few Osmia species (Goulson, 2003), no other bee species have been involved in transcontinental trade at a scale comparable to that of $A$. mellifera and B. terrestris (Aizen et al., 2019b; Geslin et al., 2017b; Goulson, 2003, 2010; Morales et al., 2017; Stout and Morales, 2009). 
In general, species introduction can involve one of three geographical and biological scenarios. One involves introduction of a subspecies where another subspecies of the same species is already resident, whether naturally or owing to a previous introduction. Examples include translocations of European subspecies of the western honey bee and of bumble bee species within Europe or North America (Bartomeus et al., 2020; Elie, 2015; Goulson, 2010) and the introduction of the African honey bee, A. m. scutellata, into the Americas, where other European subspecies had already been introduced (Schneider et al., 2004; Smith, 1991). The second scenario involves introduction where native congeners were already present, such as the introductions of the western honey bee into eastern and southern Asia and of B. terrestris in eastern Asia and South America (Goulson, 2003, 2010). The final scenario involves introduction of a bee species into a region not previously occupied by any congener, such as the original introductions of $A$. mellifera in the Americas and Oceania and of different of Bombus species in New Zealand (Howlett and Donovan, 2010; Macfarlane and Gurr, 1995; Moritz et al., 2005). These different types of introduction have initiated minor and major bee invasions (see Section 3).

Intentional species introductions, such as those motivated by commercial benefit, are much more likely to cause and maintain ecologically significant invasions if these species are continually introduced in large numbers. The rate and extent of invasion spread depends on propagule pressure-i.e. the number of individuals released in an unoccupied area (Lockwood et al., 2005; Simberloff, 2009). Accordingly, continuous supply of bees due to well-established, unregulated bee imports can subsidize and accelerate ongoing invasions. Such augmentation appears to enhance the invasion of southern South America by B. terrestris. Since 1997, more than 1.2 million colonies and queens have been continually imported into Chile, the only country in South America allowing this trade, from bumble-bee factories in Europe and Israel for greenhouse tomato pollination and open-field pollination of blueberry and other crops (Fig. 3: Aizen et al., 2019b; Montalva et al., 2011). Although B. terrestris is now well established in the wild in Chile and Argentina, and probably in Bolivia and Perú, each new importation could result in further introgression from a genetically novel propagule stock and introduction of new pathogens spilling over to the native bees, which in turn could promote the ongoing invasion (Smith-Ramírez et al., 2018). For similar reasons, trade of a bee species within its native region can have invasion-like consequences by artificially increasing the numerical and ecological dominance of the supplemented species. This effect likely 


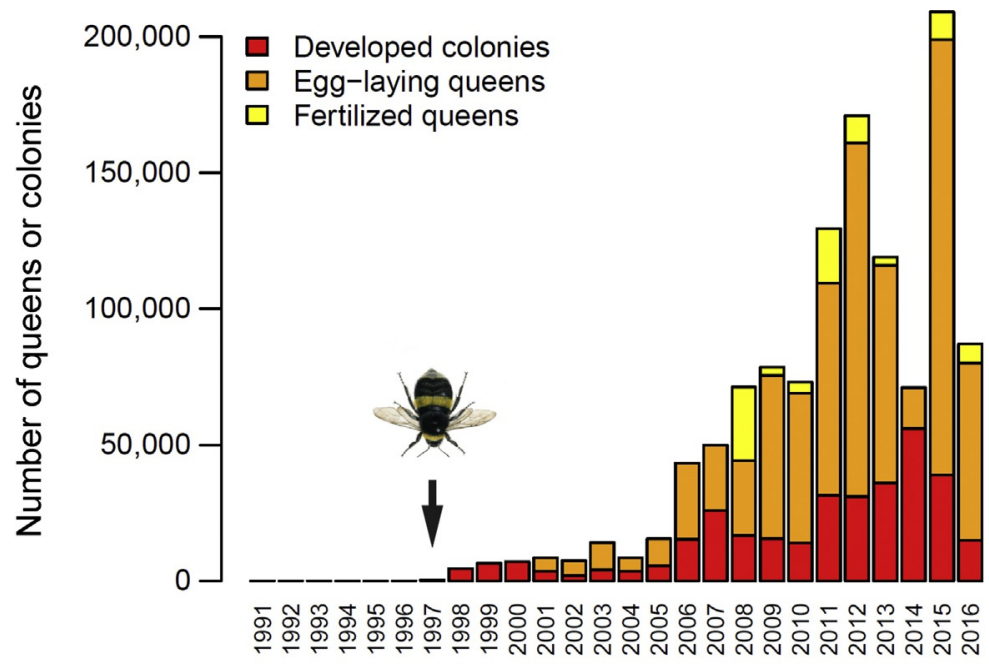

Year

Fig. 3 Numbers of colonies and queens of Bombus terrestris imported into Chile from 1997, when it was first introduced, through June 2016. Data from the Servicio Agrícola Ganadero of Chile (SAG, 2016. Data Provided Upon Request in June 2016 According to the Law of "Transparency and Access to Public Information" [Reference AR006T0000668]. Servicio Agrícola Ganadero of Chile, Santiago, Chile). Adapted from Aizen, M.A., SmithRamírez, C., Morales, C.L., Vieli, L., Sáez, A., Barahona-Segovia, R.M., Arbetman, M.P., Montalva, J., Garibaldi, L.A., Inouye, D.W., Harder, L.D., 2019b. Coordinated species importation policies are needed to reduce serious invasions globally: the case of alien bumblebees in South America. J. Appl. Ecol. 56, 100-106.

contributes to the dominance of $A$. mellifera and perhaps of $B$. terrestris among European bee assemblages (Bommarco et al., 2012; Goulson, 2010; Herrera, 2020). The consequences of growing bee trade for propagule pressure have been recognized as a key factor promoting bee invasions by the Intergovernmental Science-Policy Platform on Biodiversity and Ecosystem Service (IPBES, 2016).

\subsection{Ecological opportunities and displacement of native bees}

Once an alien species has been introduced, ecological characteristics of the new geographical area and its resident species determine whether the newcomer establishes and spreads (Davis, 2009). In particular, invasion is promoted by the existence of ecological opportunities, including the absence of ecologically similar competitors (lack of biotic resistance; Shea and Chesson, 2002), and of predators or pathogens (enemy-free space; 
Shea and Chesson, 2002), and/or the availability of mutualists (Davis, 2009). For example, successful, intentional introduction of four bumble bee species to New Zealand during the late 19th century benefited from both the natural absence of a potentially competing long-tongued bee fauna (Anderson, 2003) and human cultivation of mutualists in the form of nonnative leguminous forage crops adapted to pollination by long-tongued bees (Goulson, 2003; Macfarlane and Gurr, 1995). The latter role of nonnative mutualisms reflects a broader phenomenon of "invasion complexes", whereby alien pollinators disproportionally visit alien plants for nectar and pollen, pollinating the plants visited and promoting their reproduction (Morales and Aizen, 2002, 2006). Thus, plant and pollinator invasions can reinforce each other.

Even if related species occur in the new habitat, an invasion can succeed if the introduced species is competitively superior to residents, perhaps benefiting from the mutualistic interactions previously shaped by functionally similar residents over evolutionary time (Shea and Chesson, 2002). Indeed, most studies of the effects of invasive and managed bees on native bees have detected negative effects (Mallinger et al., 2017). Relevant traits of highly invasive bees like A. m. scutellata and B. terrestris that make them superior competitors and often dominant species in their native home ranges include sociality, diet generalization, efficient foraging, and aggressiveness (Bommarco et al., 2012; Geslin et al., 2017b; Schneider et al., 2004; Smith, 1991; Velthius and van Doorn, 2006). For example, the rapid and extensive spread of African honey bees in the Americas compared to other established $A$. mellifera subspecies resulted in part from faster colony growth aided by greater attention to pollen foraging, and in part from usurpation of established nests of European subspecies (Schneider et al., 2004). Competition for food and nest sites has also been implicated in the decline of Apis cerana in China after the introduction of European A. m. ligustica in 1896 (Yang, 2005). Bombus terrestris likely benefits from a different competitive advantage as it continues displacing the only native bumble bee in southern South America, B. dahlbomii. Although B. terrestris has a shorter proboscis than $B$. dahlbomii, it commonly robs long-tubed flowers of species previously pollinated by $B$. dahlbomii, thereby depleting the native species' nectar sources (N.M. Rosenberger, M.A. Aizen and L.D. Harder, unpublished data).

Invaders can also displace residents via apparent competition, particularly if they are vectors of pathogens that they tolerate but that are detrimental to resident species (Holt and Bonsall, 2017). Pathogen transmission from 
commercial colonies of honey bees and bumble bees may be a leading contributor to the global pollinator decline (Fürst et al., 2014; IPBES, 2016; Vanbergen and The Insect Pollinators Initiative, 2013; Vanbergen et al., 2018). For instance, introduction of colonies of invasive $B$. terrestris in South America also introduced the highly pathogenic protozoan Apicystis bombi, which infected $B$. dahlbomii and the previously introduced alien B. ruderatus (Arbetman et al., 2012). Furthermore, introduced pollinators carrying multiple pathogens can increase their infectious potential because of complex synergistic interactions. For instance, the host-shift by ectoparasitic Varroa mites to the western honey bee as a consequence of the global trade led to increased prevalence and virulence of strains of the deformed wing virus (DWV) through cycles of transmission during Varroa feeding and recombination in this honey bee host (Vanbergen et al., 2018). Furthermore, spillover of pathogenic DWV strains has occurred between managed honey bees and wild Bombus species (Fürst et al., 2014; Wilfert et al., 2016). Consequently, introduced and managed bees can facilitate the spread of new diseases to wild populations, eliciting novel epidemics that may affect population and community structure, with implications for pollination.

\subsection{Anthropogenic disturbance}

In contrast to many plant invasions, the spread of introduced bees does not appear to depend on natural or anthropogenic habitat disturbance. For example, the African honey bee and B. terrestris have spread impressively in the Americas by colonizing diverse natural habitats. Nevertheless, these and other invasive bees (e.g. B. ruderatus) thrive in human-disturbed habitats (Aizen and Feinsinger, 2003; Morales et al., 2013). For instance, Aizen and Feinsinger (1994a) found that the abundance of African honey bees increased with fragmentation of the Chaco forests of NW Argentina, whereas the abundance and diversity of native bees decreased. In addition, compared to most other bees $A$. mellifera is a long-range forager (up to $\sim 10 \mathrm{~km}$ from the hive; Beekman and Ratnieks, 2000), which may also contribute to its ubiquity in anthropogenic landscapes. This trait could explain, at least in part, the results of a meta-analytical study reporting that the abundance of feral $A$. mellifera declines more slowly with increasing distance to natural or seminatural field margins than that of most native bees (Garibaldi et al., 2011b).

Bombus terrestris can attain high densities in agroecosystems, such as raspberry fields in southern Argentina (Sáez et al., 2014) and blueberry 
fields in southern Chile (Aizen et al., 2019b). Also, conversion of meadows and seminatural pastures into arable lands and agricultural intensification in Sweden have been implicated in the demise of several specialized, long-tongued bumble bee species and increasing dominance of a generalist, short-tonged bumble bee such as B. terrestris (Bommarco et al., 2012). Overall, super-abundant and highly generalist, invasive bee species like $A$. mellifera and $B$. terrestris seem more resistant than native bees to the effects of habitat homogenization and agrochemicals, which may enable them to prosper in different disturbed habitats-including agricultural lands-where native bees do poorly (Aizen and Feinsinger, 2003; Aizen et al., 2014; Arena and Sgolastra, 2014; Morales and Aizen, 2002).

The greater resistance of invasive bees to different types of anthropogenic disturbances suggests that they will dominate impoverished bee communities in homogenous landscapes such as those created by conventional intensive agriculture (Vanbergen and The Insect Pollinators Initiative, 2013). Indeed, in those landscapes local bee assemblages seem to converge on a similar set of dominant bee species, independent of the specific anthropogenic disturbance, which can reduce $\alpha$ and $\beta$ diversity of bees (Aizen and Feinsinger, 1994a, 2003; Chacoff and Aizen, 2006; Quintero et al., 2010). On the other hand, high bee diversity can be maintained in heterogeneous agricultural landscapes that include remnants of natural and seminatural habitat (Winfree et al., 2007, 2009). Extirpation of many pollinator species by anthropogenic disturbance, particularly solitary bees, releases floral resources, including mass-flowering crops, for exploitation by the more generalist survivors (Steffan-Dewenter et al., 2002; Westphal et al., 2003). Therefore, large-scale agricultural homogenization of landscapes, while not a prerequisite for a bee invasion, indirectly favours disturbance-resistant social bees such as $A$. mellifera and $B$. terrestris.

\section{Consequences of bee invasions for crop pollination}

According to the benefit-cost perspective on plant-pollinator mutualisms elaborated in Section 2, the costs of this interspecific interaction to plants likely intensifies as bee density, and hence visitation per flower, increases. Thus, even though invasive bees, and many other bees, can enhance crop pollination at low or moderate densities, detrimental effects on agricultural yield are expected if three conditions are met: (1) invasive bees visit the flowers of many different crops; (2) individual flowers receive many visits when alien bees become invasive and attain high densities; 
and (3) very frequent visits reduce a flower's seed production because of increased direct or indirect mutualism costs, reducing overall crop yield. We discuss each of these conditions and review existing evidence from both crop and wild plants. To illustrate the consequences of invasive bees for crop yield, we present the case of commercial raspberry and B. terrestris in South America (Sáez et al., 2014, 2017, 2018) and revisit the proposal that coffee yield in tropical America increased following invasion by the African honey bee (Roubik, 2002).

\subsection{Interaction of alien bees with crop flowers}

Despite the recognized risks of species invasion for pollinators and pollination (Vanbergen et al., 2018), intentional bee introduction continues to be justified by the ability of managed bees to produce honey (Apis) and/or their apparent utility as crop pollinators (Dicks et al., 2016; IPBES, 2016). The two most-traded bees, A. mellifera and B. terrestris, are extreme generalists, enhancing their value as managed pollinators of most common pollinatordependent crops (see below). Even pollinators considered to be relative specialists may be gourmands, not gourmets. The alfalfa leaf-cutter bee (M. rotundata), for example, is increasingly employed to pollinate crops other than alfalfa and its relatives, such as canola (Westcott and Nelson, 2001).

Apis mellifera is probably the most generalized pollinator of all, visiting the flowers of thousands of plant species, participating in and, in many cases, dominating plant-pollinator networks in both its native and introduced ranges (Hung et al., 2018). Apis mellifera pollinates the flowers of about $80 \%$ of pollinator-dependent crops (Klein et al., 2007). Whether managed or feral, this bee species can dominate the pollinator assemblage of many tropical and temperate crops (Fig. 4), in some cases accounting for $>75 \%$ of all visits to flowers of disparate crops, including apple, coffee, grapefruit, macadamia, sunflower, and soybean among many others (Badano and Vergara, 2011; Blanche et al., 2006; Blettler et al., 2018; Chacoff and Aizen, 2006; Geslin et al., 2017a; Sáez et al., 2012). Apis mellifera's generalized feeding and extensive foraging range heighten its utility as a crop pollinator, especially under intensive agricultural management such as monocultural production of soybean and canola (e.g. Chiari et al., 2005; de Souza Rosa et al., 2011). For example, visit frequency by African honey bees to flowers in extensive grapefruit plantations in NW Argentina is only $\sim 10 \%$ less in the middle of plantations ( $500 \mathrm{~m}$ from the edge) than the edge, whereas visitation by native bees in the same plantations declined 


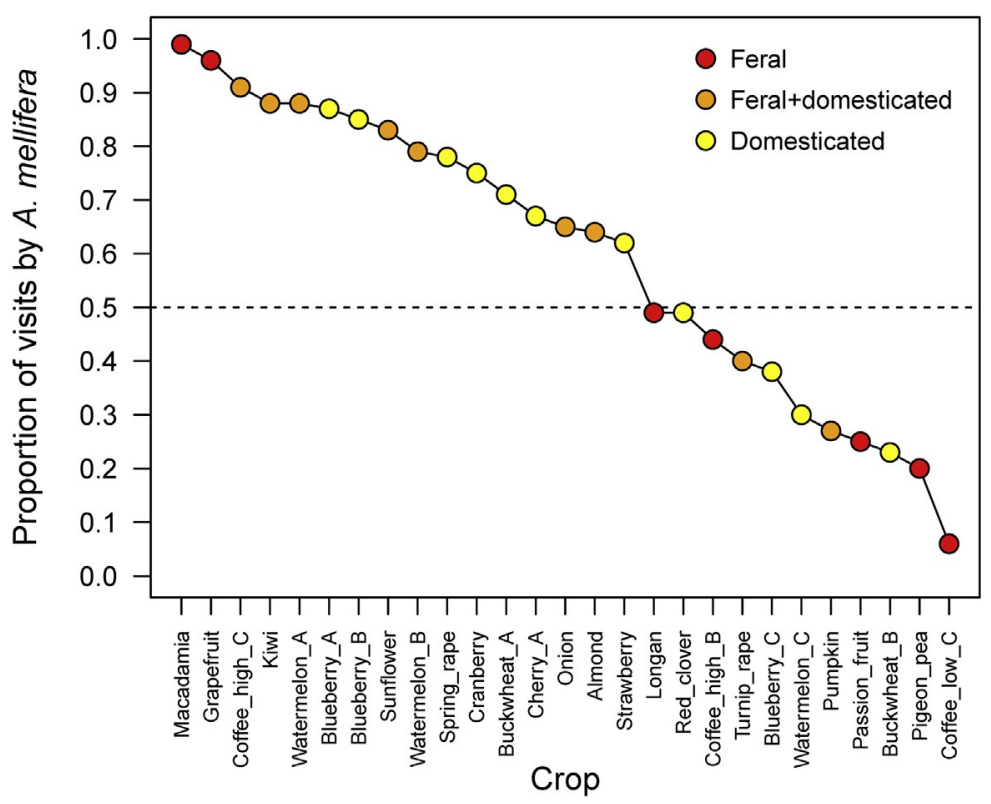

Fig. 4 Proportion of visits by domesticated and/or feral Apis mellifera to different crops, ranked in descending order. Data from Table S2 of Garibaldi, L.A., Steffan-Dewenter, I., Winfree, R., Aizen, M.A., Bommarco, R., Cunningham, S.A., Kremen, C., Carvalheiro, L.G., Harder, L.D., Afik, O., Bartomeus, I., Benjamin, F., Boreux, V., Cariveau, D., Chacoff, N.P., Dudenhöffer, J.H., Freitas, B.M., Ghazoul, J., Greenleaf, S., Hipólito, J., Holzschuh, A., Howlett, B., Isaacs, R., Javorek, S.K., Kennedy, C.M., Krewenka, K.M., Krishnan, S., Mandelik, Y., Mayfield, M.M., Motzke, I., Munyuli, T., Nault, B.A., Otieno, M., Petersen, J., Pisanty, G., Potts, S.G., Rader, R., Ricketts, T.H., Rundlöf, M., Seymour, C.L., Schüepp, C., Szentgyörgyi, H., Taki, H., Tscharntke, T., Vergara, C.H., Viana, B.F., Wanger, T.C., Westphal, C., Williams, N., Klein, A.M., 2013. Wild pollinators enhance fruit set of crops regardless of honey bee abundance. Science 339, 1608-1611: see that reference for crop details.

85\% (Chacoff and Aizen, 2006). Across agricultural landscapes, honey bees can use the flowers of both crops and of the surrounding vegetation (Russo et al., 2013).

Bumble bees also effectively pollinate many temperate plant species and crops. For example, B. terrestris visits flowers of more than half of all temperate animal-pollinated crops considered in a recent meta-analysis (Garibaldi et al., 2013), including red clover, strawberry, onion, spring rape, turnip rape, cherry, and fava bean. Another meta-analysis identified this species as the most important wild pollinator for agriculture in Europe in terms of the number of crops it pollinates, visitation frequency, and economic contribution to crop production (Kleijn et al., 2015). Bumble bees are 
particularly useful pollinators of crops with poricidal anthers, such as tomato and eggplant, because unlike honey bees they can actively produce the vibrations needed to remove pollen from anthers (buzz-pollination; Buchmann, 1983). Although most B. terrestris colonies imported to Chile have been used for tomato pollination, particularly in greenhouses, they have also been used to pollinate blueberry, avocado, strawberry, canola, pepper, melon, and broccoli (Estay, 2007). In general, introduced bumble bees, including $B$. terrestris, use both alien and native plant species extensively (Howlett and Donovan, 2010; Montalva et al., 2011).

\subsection{Visit frequencies of alien bees}

Even though invasive bees may be effective crop pollinators at low densities, they can be detrimental to agriculture and to plant sexual reproduction in general when they become extremely abundant (see Section 2). These effects can arise from increasing direct costs associated with high frequencies of flower visitation (Fig. 1A, Table 1) or indirect costs arising from extreme dominance of pollinator assemblages (Fig. 1B-D). The limited available evidence supports the premise that invasive bees commonly become extremely abundant and dominant (Morales et al., 2017).

The invasive African honey bee is probably the most abundant bee throughout the Neotropics. For instance, in dry Chaco forest of NW Argentina the African honey bee accounts for $>90 \%$ of visits to Prosopis nigra inflorescences and about 50\% of visits to Parkinsonia praecox flowers (Aizen and Feinsinger, 1994a). A reanalysis of data from Aizen and Feinsinger (1994a) suggests that African honey bees were respectively two and three times more abundant visitors to the flowers of these two native tree species than all other species combined (Fig. 5). Similarly, feral African honey bees represent $>90 \%$ of visitors to cultivated citrus flowers in NW Argentina (Chacoff and Aizen, 2006). These data reveal pollination environments dominated by invasive African honey bees.

Invasive bumble bees can also attain extreme densities, as illustrated by examples from successive invasions of the temperate forests of NW Patagonia by B. ruderatus and B. terrestris (Morales et al., 2017). Bee visits to Alstroemeria aurea growing in montane Nothofagus forests in the Challhuaco Valley, Argentina, between 1994 and 2013 provide graphic evidence. Immediately before the first invasion by alien Bombus, $A$. aurea flowers received an average of $\sim 0.075$ visits $h^{-1}$ by the native $B$. dahlbomii. Bombus ruderatus first appeared in this forest during 1996, and by 2008 
A

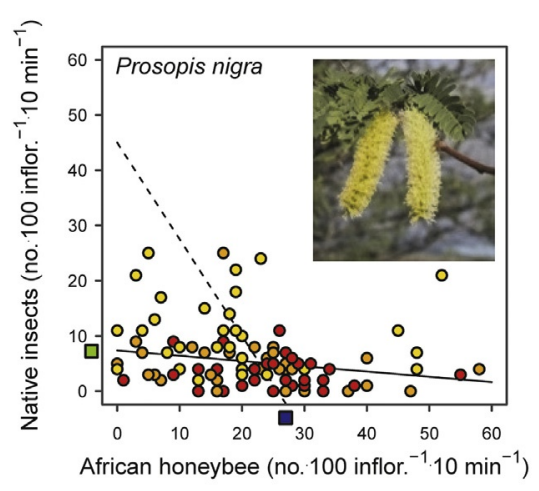

C

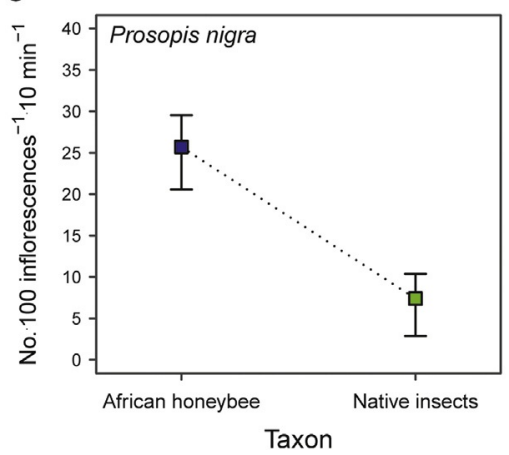

B

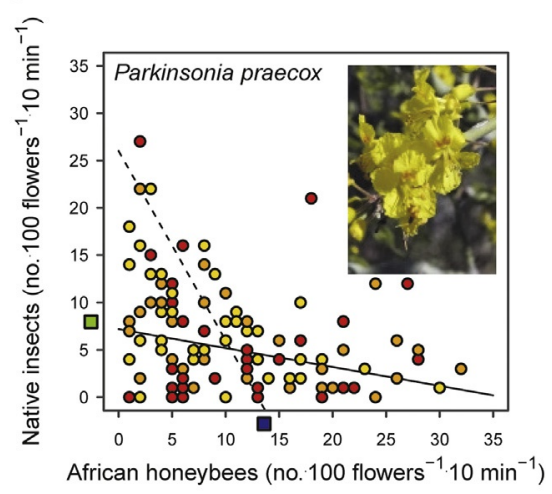

$\mathrm{D}$

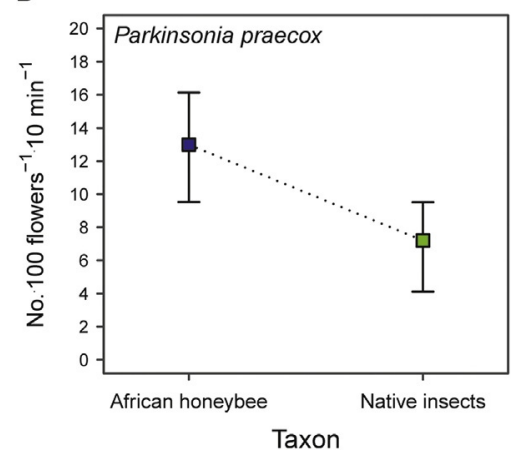

Fig. 5 Frequencies of visits to (A and C) the brush-like inflorescences of Prosopis nigra and (B and $D$ ) individual flowers of Parkinsonia praecox by feral African honey bees (Apis mellifera scutellata) and native insects in a fragmented dry Chaco forest of NW Argentina. Panels ( $A$ and $B$ ) depict visit frequencies for trees isolated in small fragments ( $<1$ ha, red circles), in large fragments ( $>1$ ha, orange circles), and in continuous forests (yellow circles). Lines represent estimated quantile regressions of variation in median visit frequency by African honey bees as a function of visit frequency by native insects (dashed lines) and of visit frequency by native insects as a function of visit frequency by African honey bees (solid lines). The coloured squares indicate the visitation of each insect group on its own, as estimated by the regression intercepts for visitation by African honey bees (blue squares) and by native insects (green squares). Panels ( $C$ and $D$ ) compare these intercepts ( $\pm 95 \%$ confidence interval) as estimated by the quantile regressions. Data from Aizen, M.A., Feinsinger, $P$., 1994a. Habitat fragmentation, native insect pollinators, and feral honey bees in Argentine 'Chaco Serrano'. Ecol. Appl. 4, 378-392.

B. dahlbomii had been extirpated. During 2006, visitation to $A$. aurea flowers by $B$. ruderatus peaked at $\sim 0.12$ visits $h^{-1}$. The subsequent invasion by $B$. terrestris reached the Challhuaco Valley in 2007, and since 2009 $A$. aurea flowers have received an average of $\geq 0.15$ visits $h^{-1}$, doubling 
the visit frequency by its original native pollinator (Morales et al., 2013; C.M. Morales, unpublished). More general evidence comes from a survey conducted during 2011 throughout the Patagonian Andes, when the native $B$. dahlbomii still occupied southern landscapes not yet reached by $B$. terrestris or $B$. ruderatus and comparisons between habitats with and without $B$. terrestris alone were still possible. The abundance of $B$. terrestris in invaded areas was 10 times greater than that of $B$. dahlbomii in as-yetuninvaded areas (Morales et al., 2013). Similarly, raspberry flowers in commercial fields in NW Patagonia receive one to two orders of magnitude more visits than those in fields in the native range of B. terrestris in Europe (Sáez et al., 2014, 2018). Clearly, bumble bees can become unusually abundant and visit flowers extremely frequently once they have invaded new regions.

\subsection{Benefit-cost relations of interacting with alien bees}

Mounting evidence demonstrates a reduction in seed output arising from direct costs of interacting with highly abundant, dominant pollinators (Fig. 1A). An extreme example involves fruit set by South American Capparis atamisquea, which fails almost completely in intensively visited plants (Morris et al., 2010). In NW Argentina, high visitation by invasive African honey bees along with the transfer of self-pollen (see below) may explain decreased fruit set by C. atamisquea in fragmented forests (Aizen and Feinsinger, 1994b). More broadly, a recent meta-analysis of the effects of the western honey bee on crop productivity based on 16 crops found maximum fruit or seed set by flowers that received 8-10 honey-bee visits during their lives, but reduced seed set by flowers subject to more visits (Rollin and Garibaldi, 2019). Such peaked relations are consistent with saturating gross benefits, but linearly increasing costs for female reproductive success by plants as pollinator visitation increases (Fig. 2A).

Evidence also indicates reduced seed output arising from indirect costs via decreasing abundance and diversity of other pollinators. In particular, visit frequency by native insects can vary inversely with that of honey bees when the latter dominates a floral resource (Aizen and Feinsinger, 1994a; Mallinger et al., 2017; Rollin and Garibaldi, 2019), thereby affecting plant reproduction (e.g. Aizen and Feinsinger, 1994b; Badano and Vergara, 2011). Pollen-collecting honey bees can decrease per-visit and total pollination by nectar-seeking pollinators (Chalcoff et al., 2012; Hargreaves et al., 2010), illustrating the indirect costs depicted in Fig. 1B. Also, the displacement of native flower visitors by a highly abundant visitor, either 
native or alien, can decrease visit frequency by effective native pollinators (Fig. 1C) or pollinator diversity and associated niche complementarity (Fig. 1D) (Albrecht et al., 2012; Brittain et al., 2013a). For instance, replacement of native bees and increasing transfer of self-pollen by the African honey bee might, at least in part, explain widespread decreasing seed production in fragmented dry forests of NW Argentina (Aizen and Feinsinger, 1994a,b). In short, indirect costs (Fig. 1B-D) could result in the monotonic decrease of crop yield with increasing dominance of invasive bees (Fig. 2B).

\subsection{Case study 1: Bumble-bee invasion and raspberries}

Studies of commercial raspberry, Rubus idaeus, in NW Patagonia provide a detailed example of how extremely high visitation by an invasive bee can impose direct costs on crop productivity (Morales, 2009; Sáez et al., 2014, 2017, 2018). The eruption of the Puyehue Volcano in the southern Andes in 2011 created a natural experiment for testing the effects of invasive $B$. terrestris on fruit production by commercial raspberries. A downwind gradient of decreasing ash deposition caused a corresponding increase in the average frequency of visits by $B$. terrestris to raspberry flowers from $<5$ daily visits per flower in fields near the volcano to $>150$ visits in fields with little ashfall. Surprisingly, this increased visitation did not improve the number of carpels that developed ripe drupelets per raspberry flower. Instead, drupelet set decreased about $40 \%$ along this gradient, so that fewer bumble-bee visits resulted in better-quality raspberry fruits (Sáez et al., 2014). The poor drupelet set in fields farthest from the volcano was associated with two effects of increased visit frequency. As expected, the number of pollen grains deposited on stigmas increased with visit frequency, but this effect saturated after a few bumble-bee visits (Sáez et al., 2014). The unexpected negative effect arose from a strong positive association of the frequency of carpels with broken styles to visitation frequency, which increased throughout the gradient from about $10 \%$ in fields close to the volcano to $90 \%$ in more distant fields (Fig. 6A). Style breakage diminished both the chance of stigmatic pollen deposition and, for pollinated pistils, the chance that pollen tubes reached the ovary and fertilized the ovule (Sáez et al., 2018). A mechanistic model based on these relations predicted that just $5-10$ bumble-bee visits per daythe range of visit frequencies observed in those raspberry fields closest to the volcano-should maximize the number of drupelets per fruit (Sáez et al., 2018). This case exemplifies the effect on plant reproduction of increasing direct mutualism costs depicted in Fig. 2A. 

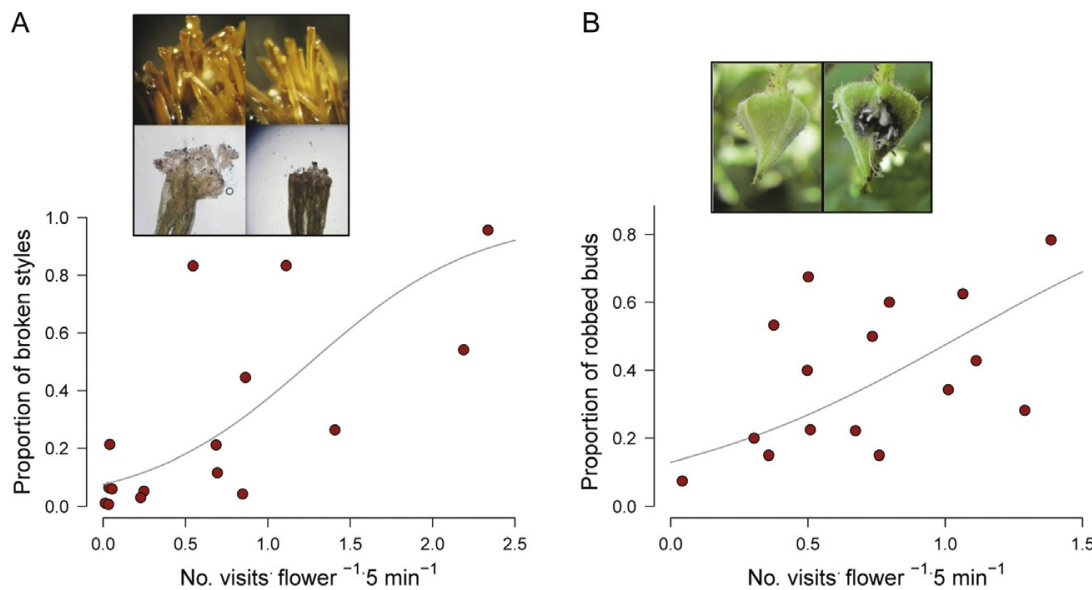

Fig. 6 Relations of interaction costs to visit rates of Bombus terrestris in fields of raspberry (Rubus idaeus) in NW Patagonia, Argentina, including the proportions of (A) broken styles and (B) robbed flower buds. The fitted logistic regressions are (A) $1 /\left(1+\mathrm{e}^{2.5-1.98 x}\right)(z=5.74, P<0.0001)$ and (B) $1 /\left(1+\mathrm{e}^{1.9-1.79 x}\right)(z=2.63, P=0.0086)$ (Sáez et al., 2014, 2017). The images show $(A)$ magnified $(\times 25)$ and microscopic $(\times 100)$ pictures of undamaged (left) and damaged (right) styles and (B) pictures of an intact and a robbed flower bud. Adapted and assembled from Sáez, A., Morales, C.L., Ramos, L.Y., Aizen, M.A., 2014. Extremely frequent bee visits increase pollen deposition but reduce drupelet set in raspberry. J. Appl. Ecol. 51, 1603-1612; Sáez, A., Morales, C.L., Garibaldi, L.A., Aizen, M.A., 2017. Invasive bumble bees reduce nectar availability for honey bees by robbing raspberry flower buds. Basic Appl. Ecol. 19, 1-10.

In addition to the direct costs of style breakage, increased visitation by $B$. terrestris to raspberry flowers imposes an indirect cost: nectar robbery from flower buds. Raspberry flowers produce most nectar in a single pulse before anthesis, with little replenishment when nectar is removed following anthesis (Sáez et al., 2017). When competition for nectar increases, some bumble bees, including $B$. terrestris, switch from "legitimate" flower visits to "illegitimate" robbery of nectar, thereby affecting pollination. In general, nectar robbery damages flowers and rarely results in pollination (Irwin et al., 2010). In particular, B. terrestris robs and damages raspberry flower buds before they open, affecting their attractiveness and nectar availability for "legitimate" pollinators after buds open. Sáez et al. (2017) found that the proportion of robbed buds increased from about 10 to $80 \%$ with increasing bumble-bee visitation (Fig. 6B). Correspondingly, visitation by managed honey bees, the second most frequent raspberry visitor in NW Patagonia, decreased strongly with increasing visitation by bumble bees (Sáez et al., 2017). Honey bees, which are introduced but not invasive in Patagonia, 
caused less style damage to raspberry flowers than B. terrestris, but they provide similar pollination effectiveness (Sáez et al., 2014). Thus, competitive exclusion of honey bees by $B$. terrestris robbers would indirectly reduce raspberry fruit production, as depicted in Fig. 1C.

\subsection{Case study 2: Coffee and the African honey bee in the Americas, revisited}

Like that of B. terrestris, the invasion of the African honey bee could have influenced crop yield in the New World. In particular, Roubik (2002) suggested that the African honey bee enhanced crop production after it invaded the Americas due to its high abundance and generalist foraging. He tested this proposal by comparing mean coffee yield in tropical countries of the Western Hemisphere before and after 1981, about the time when the African honey bee was first observed in Central America. A paired $t$-test detected statistically greater coffee production after 1981. This difference was not detected for tropical countries of the Old World (Africa and Asia), for which the honey-bee fauna did not change, although there was a tendency for greater yield post-1981, as in the New World. Roubik interpreted this contrast as supporting the hypothesis that the African honey-bee invasion had boosted pollination services throughout the Neotropics. However, we question this interpretation because the arrival date of the African honey bee differed among the New World countries involved (Moritz et al., 2005), such that in some countries the increase in coffee yield may have preceded the arrival of this bee.

We re-examined the hypothesis of expected benefits of honey bees for coffee production more directly by assessing the temporal trends in yield in individual countries with respect to the specific estimated arrival dates of the African honey bee to each of them. A variety of patterns emerge (Fig. 7). A minority of countries, such as Colombia, Panama, Nicaragua, and Perú, experienced increased average coffee yield coincident with or a few years after the invasion of African honey bees, consistent with Roubik's hypothesis. Other countries, such as Bolivia, Guatemala, and Honduras, exhibited a long-term positive trend in coffee yield that preceded the African honey-bee invasion and was not altered by it. For these countries, then, increases in coffee production after 1981 cannot be attributed to the arrival of African honey bees. For a third set of countries, including Costa Rica, Ecuador, El Salvador, and Mexico, coffee production declined with the onset of the invasion of African honey bees or shortly thereafter. 


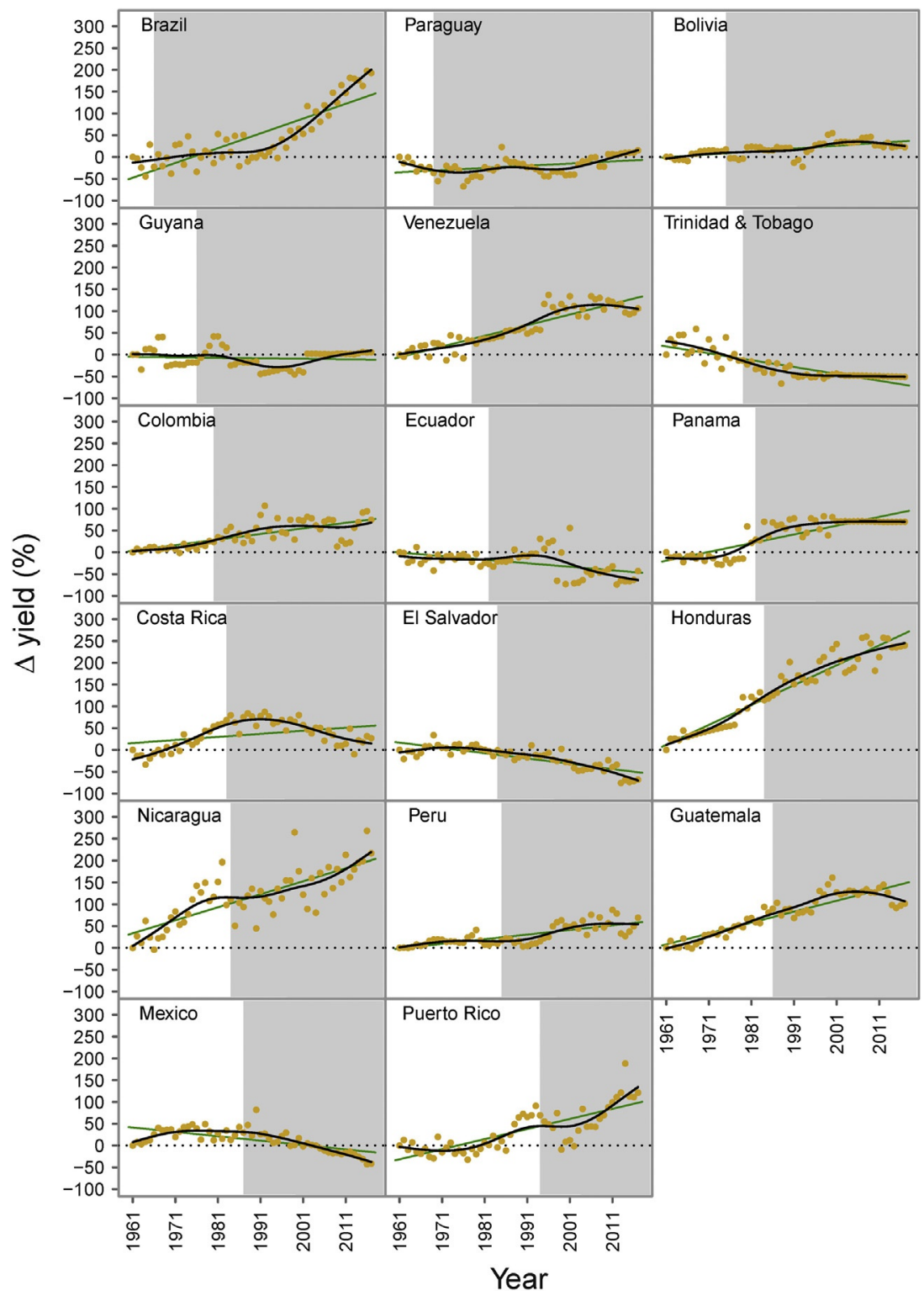

Fig. 7 Temporal trends of relative coffee yield from 1961 to 2017 for 17 tropical South American and Central American countries. For each country, $\Delta$ yield is the difference in yield during year $t$ relative to that during 1961 and transition between the white and grey zones denotes the year of invasion by the African honey bee based on invasion-front isoclines from Moritz et al. (2005: Fig. 2). Given the large area of Brazil, we used 1966 rather than 1957 (i.e. when African first escaped captivity near Sao Paulo) as the estimated average invasion year of that entire country. For each country, the black curve describes the temporal change in mean yield (smoothing spline with a smoothing parameter $=0.8$ ), whereas the green line represents the average long-term trend (linear regression). Data from FAOSTAT, 2020. Data available at http://faostat.fao. org/site/526/default.aspx (Accessed 25.1.2020). 
This heterogeneity in response fails to support the hypothesis of wideranging benefits of invasion by the African honey bee on coffee yield.

Without excluding other non-pollination explanations such as the replacement of shade by sun coffee (Guhl, 2008), the observed variety of effects agrees with the diversity of outcomes expected from the effects of diverse bee densities on seed production (Section 2). Although limited country-specific data about visitation rates and pollination precludes direct analysis of the effects of the African honey bee on coffee yield, insights into the nature of these effects can be gained by considering the pollination requirements of the two most cultivated coffee species. Both self-sterile Coffea canephora, cultivated mostly in the Old World, and self-fertile C. arabica, cultivated most commonly in the New World, depend on insect visitation for high seed set and have generalist flowers that provide visitors with nectar and pollen (Ngo et al., 2011). For example, a study of seven sets of coffee plantations (three C. arabica, four C. canephora) in five countries found that fruit set increased strongly with increasing visitation and diversity of wild pollinators (Garibaldi et al., 2013). However, of the three sets visited by A. mellifera, coffee yield varied positively with visitation rate for only the set of plantations where honey-bee visits were in the minority. In the other two sets, where honey-bee visits predominated, fruit set failed to show an increase with increased visit frequency. Coffee production generally benefits from insect pollination, but it appears that whether it benefits from honey-bee pollination per se depends on whether $A$. mellifera dominates the pollinator assemblage.

A more detailed study on C. arabica in Mexico by Badano and Vergara (2011) is particularly revealing. Badano and Vergara found a positive effect of overall pollinator diversity on coffee fruit set, but this effect was counteracted by increased numerical dominance of honey bees and consequent reduction in the diversity of the pollinator assemblage as a whole. The authors proposed that a diverse assemblage increases the chances of including native pollinators that move frequently among plants, thereby carrying outcross pollen that increases seed set (Hipólito et al., 2020). Honey bees largely restricted their foraging to individual coffee plants, transferring pollen primarily between the flowers of the same plant. Thus, Badano and Vergara's results indicate indirect costs of increased honey-bee visitation to coffee production via decreased diversity of the bee assemblage, which reduced pollination quality. Other density-dependent direct and indirect costs associated with active pollen harvesting (e.g. pollen theft) by honey bees may also be involved. 
Together, this evidence suggests that honey bees may improve coffee yield when other pollinators visit infrequently, but when alternative pollinators are abundant, addition of honey bees can have neutral or negative effects. This demonstrated context dependence is inconsistent with the conclusion that the invasion of tropical America by the African honey bee generally improved the production of coffee or other crops.

\section{The future of agriculture in a context of bee invasions}

That more bee visits are always better is a prevailing paradigm in crop pollination management (Garibaldi et al., 2020). Even though the saturation of seed and fruit set with increasing numbers of pollinator visits is recognized (e.g. Bell and Cresswell, 1998; Carlson, 2007), farmers often deploy more honey-bee hives than needed "just in case" (Garibaldi et al., 2020). This "just in case" practice is also commonly applied in the use of other agricultural inputs such as fertilizers, herbicides, and pesticides (e.g. Norsworthy et al., 2012; Schiesari et al., 2013). The conceptual framework we propose (Section 2) and empirical evidence we present indicate that, in addition to being unnecessary and possibly wasteful of time and resources because lower densities of pollinators saturate plant yield capability, this practice may actually diminish yields of pollinator-dependent crops (e.g. Brittain et al., 2010; Carvalheiro et al., 2012).

As anthropogenic environmental disturbance increases exponentially and climates warm, community diversity declines in all taxonomic groups and "weedy" species, which often include successful invaders (Dawson et al., 2011; Schlaepfer et al., 2010), increasingly dominate many landscapes (Brook et al., 2008; Tilman and Lehman, 2001). In particular, richness and evenness of native bee assemblages are declining globally (Arbetman et al., 2017; IPBES, 2016; Kerr et al., 2015; Soroye et al., 2020; Zattara and Aizen, 2019), as most pollinator species suffer but some species thrive under habitat destruction and global warming (Aizen and Feinsinger, 2003; Bommarco et al., 2012; Herrera, 2020). For instance, B. terrestris is increasing in relative abundance and dominating pollinator assemblages in Scandinavia, within its native European range (Bommarco et al., 2012). Even if overall visitation frequency by insects as a whole does not change, indirect costs associated with the rising dominance of one or a few species of flower visitors, such as $A$. mellifera or $B$. terrestris, will likely increase. If these and other "weedy" generalist pollinators continue to thrive under climate and landscape change, they may exclude specialist pollinators 
(Miller-Struttmann et al., 2015; Schweiger et al., 2010) that might pollinate particular crops more effectively (Garibaldi et al., 2015). For example, decreases in red clover yield in Sweden have been linked, at least in in part, to the increasing dominance of $B$. terrestris and the decline of morespecialized long-tonged bumble bees (Bommarco et al., 2012). Locally, ill-considered pollinator management, such as overstocking a crop field with honey-bee hives or a greenhouse with bumble-bee colonies, might unexpectedly compromise crop yield by aggravating direct and indirect mutualism costs (Rollin and Garibaldi, 2019; Section 2).

Current trends in land use include continuous expansion of agricultural land cultivated with pollinator-dependent crops (Aizen et al., 2008a, 2019a). We propose that the productivity of agricultural landscapes dominated by pollinator-dependent crops may decline for two contrasting reasons: too few or too many bees of just one or a few species (see also Deguines et al., 2014). On the one hand, in extensive monocultures and other industrially managed agricultural landscapes devoid of native bees and other pollinators, even managed bees could perform poorly and suffer high mortality because of unbalanced diets and/or high pesticide exposure (Branchiccela et al., 2019; Goulson et al., 2015; Mancini et al., this issue). On the other hand, pollinators that thrive in highly disturbed habitats, such as the invasive African honey bee, may reduce crop yield because of increasing direct and indirect interaction costs when they are too abundant and dominant.

The results compiled and discussed in this contribution and elsewhere (Aizen et al., 2014, 2019b) should alert governments, farmers, beekeepers, conservationists, and other stakeholders to the detrimental consequences of extensive trade in bees within and beyond the native ranges of the traded species (Dicks et al., 2016; IPBES, 2016). These consequences include negative impacts on native bee faunas and beekeeping via competition and disease transmission, and on crop yield. Our conclusions question the main justification for the currently booming bee trade: enhancement of pollination services and, to a lesser extent, honey production. In addition to sparking new bee invasions, this trade continues to augment ongoing bee invasions such as that of B. terrestris in South America (Aizen et al., 2019b; Smith-Ramírez et al., 2018). Impacts on crop yield should be thus recognized as important considerations in risk analyses of the bee trade. These analyses should consider the consequences of bee trade not only for target crops, but also for other crops and native biological communities within the countries of introduction and across international boundaries. As the impact of B. terrestris in South America illustrates, bumble-bee trade can 
indeed enhance greenhouse tomato production in Chile (Estay, 2007), but when they escape management these bees can impair the yield of open-air crops, such as raspberries, and cause widespread extirpation of native species, such as $B$. dahlbomii, in both Chile and neighbouring Argentina (Aizen et al., 2019b). What is the cost of these impacts compared to the benefits of increased tomato production? The existence of such impacts argues for restriction of the trade in bees to the rearing and use of native bees at a local scale.

Elimination of established invasive bees is unfortunately impractical in most cases. Nevertheless, ongoing invasions may be slowed by stopping the importation of non-native species instead of continuing to add "more fuel to the fire" (Smith-Ramírez et al., 2018). The agricultural impacts of invasive bees can also be somewhat offset by enhancing conditions for native pollinators, which generally increase crop yield when they are abundant and diverse (Garibaldi et al., 2013), through enhancement of ecological infrastructure at different spatial scales (Faichnie et al., this issue). At the regional scale, this goal can be achieved by increasing landscape heterogeneity, such as enhancing mosaics of restored natural and seminatural habitat patches interspersed with agricultural fields cultivated with diverse crops, and by regulating agrochemical inputs (Garibaldi et al., 2014; Kovács-Hostyánszki et al., 2017). At the local scale, relevant management includes reducing field sizes, enriching field margins with flowering plants, minimizing pesticide and herbicide drifting, and providing nesting resources for bee and non-bee pollinators (Garibaldi et al., 2014; Hobbs, 1967; Howlett et al., this issue; Kovács-Hostyánszki et al., 2017). The ideal result would be the replacement of different anthropogenic inputs, including managed bees, while promoting and supporting ecosystem services provided by naturally occurring biodiversity through increasing ecological intensification (Garibaldi et al., 2019; Kovács-Hostyánszki et al., 2017). In particular, increased diversity of native pollinators should regulate the abundance or decrease the relative importance of super-abundant pollinators, while ensuring more stable pollination services (Garibaldi et al., 2011b, 2013). Put simply, future agricultural landscapes should be managed for increased biodiversity and reduced dominance of single species, whether crop or bee.

\section{Acknowledgements}

The authors acknowledge the support of the SURPASS2 project funded under the Newton Fund Latin America Biodiversity Programme: Biodiversity-Ecosystem Services for Sustainable Development, grants awarded by the Natural Environment Research 
Council of Great Britain (NERC) [NE/S011870/1], the National Scientific and Technical Research Council of Argentina (CONICET) [RD 1984/19], the São Paulo Research Foundation (FAPESP) [2018/14994-1], the National Commission for Scientific and Technological Research of Chile (CONICYT). They also acknowledge the support of the National Fund for Scientific and Technological Research of Argentina (FONCYT) [PICT 2015-2333, PICT 2018-2145, PICT-2018-00941], National Geographic Society [NGS-57001R-19], Universidad Nacional de Río Negro [PI 40-B-567], the 2017-2018 Belmont Forum and BiodivERsA joint call for research proposals (under the BiodivScen ERA-Net COFUND programme and with the funding organisations AEI, NWO, ECCyT and NSF), and the Natural Science and Engineering Research Council of Canada [RGPIN-2018-03907].

\section{References}

Acosta, A.L., Giannini, T.C., Imperatriz-Fonseca, V.L., Saraiva, A.M., 2016. Worldwide alien invasion: a methodological approach to forecast the potential spread of a highly invasive pollinator. PLoS One 11, e0148295.

Aizen, M.A., Feinsinger, P., 1994a. Habitat fragmentation, native insect pollinators, and feral honey bees in Argentine 'Chaco Serrano'. Ecol. Appl. 4, 378-392.

Aizen, M.A., Feinsinger, P., 1994b. Forest fragmentation, pollination, and plant reproduction in a Chaco dry forest, Argentina. Ecology 75, 330-351.

Aizen, M.A., Feinsinger, P., 2003. Bees not to be? Responses of insect pollinator faunas and flower pollination to habitat fragmentation. In: Bradshaw, G.A., Marquet, P.A., Ronnenberg, K.L. (Eds.), How Landscapes Change: Human Disturbance and Ecosystem Disruptions in the Americas. Springer, New York, pp. 111-129.

Aizen, M.A., Harder, L.D., 2009. The global stock of domesticated honey bees is growing slower than agricultural demand for pollination. Curr. Biol. 19, 915-918.

Aizen, M.A., Garibaldi, L.A., Cunningham, S.A., Klein, A.M., 2008a. Long-term global trends in crop yield and production reveal no current pollination shortage but increasing pollinator dependency. Curr. Biol. 18, 1572-1575.

Aizen, M.A., Morales, C.L., Morales, J.M., 2008b. Invasive mutualists erode native pollination webs. PLoS Biol. 6, e31.

Aizen, M.A., Morales, C.L., Vázquez, D.P., Garibaldi, L.A., Sáez, A., Harder, L.D., 2014. When mutualism goes bad: density-dependent impacts of introduced bees on plant reproduction. New Phytol. 204, 322-328.

Aizen, M.A., Aguiar, S., Biesmeijer, J.C., Garibaldi, L.A., Inouye, D.W., Jung, C., Martins, D.J., Medel, R., Morales, C.L., Ngo, H., Pauw, A., Paxton, R.J., Sáez, A., Seymour, C.L., 2019a. Global agricultural productivity is threatened by increasing pollinator dependence without a parallel increase in crop diversification. Glob. Chang. Biol. 25, 3516-3527.

Aizen, M.A., Smith-Ramírez, C., Morales, C.L., Vieli, L., Sáez, A., Barahona-Segovia, R.M., Arbetman, M.P., Montalva, J., Garibaldi, L.A., Inouye, D.W., Harder, L.D., 2019b. Coordinated species importation policies are needed to reduce serious invasions globally: the case of alien bumblebees in South America. J. Appl. Ecol. 56, 100-106.

Albrecht, M., Schmid, B., Hautier, Y., Müller, C.B., 2012. Diverse pollinator communities enhance plant reproductive success. Proc. R. Soc. B Biol. Sci. 279, 4845-4852.

Anderson, S.H., 2003. The relative importance of birds and insects as pollinators of the New Zealand flora. N. Z. J. Ecol. 27, 83-94.

Andersson, S., 1999. The cost of floral attractants in Achillea ptarmica (Asteraceae): evidence from a ray removal experiment. Plant Biol. 1, 569-572. 
Arbetman, M.P., Meeus, I., Morales, C.L., Aizen, M.A., Smagghe, G., 2012. Alien parasite hitchhikes to Patagonia on invasive bumblebee. Biol. Invasions 15, 489-494.

Arbetman, M.P., Gleiser, G., Morales, C.L., Williams, P., Aizen, M.A., 2017. Global decline of bumblebees is phylogenetically structured and inversely related to species range size and pathogen incidence. Proc. R. Soc. B Biol. Sci. 284, 20170204.

Arena, M., Sgolastra, F., 2014. A meta-analysis comparing the sensitivity of bees to pesticides. Ecotoxicology 23, 324-334.

Armitage, P., 2018. Regulatory Framework for the Importation of Honey Bees in Canada. vol. 34. BeesCene, pp. 42-47.

Arretz, P.V., Macfarlane, R.P., 1986. The introduction of Bombus ruderatus to Chile for red clover pollination. Bee World 67, 15-22.

Ashman, T.-L., 2004. Flower longevity. In: Nooden, L.D. (Ed.), Cell Death in Plants. Elsevier, London, UK, pp. 349-362.

Ashman, T.L., Schoen, D.J., 1994. How long should flowers live? Nature 371, 788-791.

Badano, E.I., Vergara, C.H., 2011. Potential negative effects of exotic honey bees on the diversity of native pollinators and yield of highland coffee plantations. Agric. For. Entomol. 13, 365-372.

Bartomeus, I., Park, M.G., Gibbs, J., Danforth, B.N., Lakso, A.N., Winfree, R., 2013. Biodiversity ensures plant-pollinator phenological synchrony against climate change. Ecol. Lett. 16, 1331-1338.

Bartomeus, I., Molina, F.P., Hidalgo-Galiana, A., Ortego, J., 2020. Safeguarding the genetic integrity of native pollinators requires stronger regulations on commercial lines. Ecol. Solut. Evid. 1, e12012.

Baude, M., Kunin, W.E., Boatman, N.D., Conyers, S., Davies, N., Gillespie, M.A.K., Morton, R.D., Smart, S.M., Memmott, J., 2016. Historical nectar assessment reveals the fall and rise of floral resources in Britain. Nature 530, 85-88.

Beekman, M., Ratnieks, F.L.W., 2000. Long-range foraging by the honeybee, Apis mellifera L. Funct. Ecol. 14, 490-496.

Bell, S.A., Cresswell, J.E., 1998. The phenology of gender in homogamous flowers: temporal change in the residual sex function of flowers of oil-seed rape (Brassica napus). Funct. Ecol. 12, 298-306.

Biesmeijer, J.C., Roberts, S.P.M., Reemer, M., Ohlemuller, R., Edwards, M., Peeters, T., Schaffers, A.P., Potts, S.G., Kleukers, R., Thomas, C.D., 2006. Parallel declines in pollinators and insect pollinated plants in Britain and the Netherlands. Science $313,351-354$.

Blackburn, T.M., Essl, F., Evans, T., Hulme, P.E., Jeschke, J.M., Kühn, I., Kumschick, S., Marková, Z., Mrugała, A., Nentwig, W., Pergl, J., Pyšek, P., Rabitsch, W., Ricciardi, A., Richardson, D.M., Sendek, A., Vilà, M., Wilson, J.R.U., Winter, M., Genovesi, P., Bacher, S., 2014. A unified classification of alien species based on the magnitude of their environmental impacts. PLoS Biol. 12, e1001850.

Blanche, K.R., Ludwig, J.A., Cunningham, S.A., 2006. Proximity to rainforest enhances pollination and fruit set in orchards. J. Appl. Ecol. 43, 1182-1187.

Blettler, D.C., Fagúndez, G.A., Caviglia, O.P., 2018. Contribution of honeybees to soybean yield. Apidologie 49, 101-111.

Bommarco, R., Lundin, O., Smith, H.G., Rundlöf, M., 2012. Drastic historic shifts in bumble-bee community composition in Sweden. Proc. R. Soc. B Biol. Sci. 279, 309-315.

Bosch, J., Kemp, W.P., 2002. Developing and establishing bee, species as crop pollinators: the example of Osmia spp. (Hymenoptera: Megachilidae) and fruit trees. Bull. Entomol. Res. 92, 3-16.

Branchiccela, B., Castelli, L., Corona, M., Díaz-Cetti, S., Invernizzi, C., Martínez de la Escalera, G., Mendoza, Y., Santos, E., Silva, C., Zunino, P., Antúnez, K., 2019. Impact of nutritional stress on the honeybee colony health. Sci. Rep. 9, 10156. 
Brittain, C.A., Vighi, M., Bommarco, R., Settele, J., Potts, S.G., 2010. Impacts of a pesticide on pollinator species richness at different spatial scales. Basic Appl. Ecol. 11, 106-115.

Brittain, C., Kremen, C., Klein, A.-M., 2013a. Biodiversity buffers pollination from changes in environmental conditions. Glob. Chang. Biol. 19, 540-547.

Brittain, C., Williams, N., Kremen, C., Klein, A.M., 2013b. Synergistic effects of non-Apis bees and honey bees for pollination services. Proc. R. Soc. B Biol. Sci. 280, 1-7.

Bronstein, J.L., 2001. The costs of mutualism. Integr. Comp. Biol. 41, 825-839.

Brook, B.W., Sodhi, N.S., Bradshaw, C.J.A., 2008. Synergies among extinction drivers under global change. Trends Ecol. Evol. 23, 453-460.

Brown, J.H., Kodric-Brown, A., 1977. Turnover rates in insular biogeography: effect of immigration on extinction. Ecology 58, 445-449.

Buchmann, S.L., 1983. Buzz pollination in angiosperms. In: Jones, C.E., Little, J.R. (Eds.), Handbook of Experimental Pollination Biology. Van Nostrand Reinhold, New York, pp. 73-113.

Carlson, J.E., 2007. Male-biased nectar production in a protandrous herb matches predictions of sexual selection theory in plants. Am. J. Bot. 94, 674-682.

Carvalheiro, L.G., Seymour, C.L., Nicolson, S.W., Veldtman, R., 2012. Creating patches of native flowers facilitates crop pollination in large agricultural fields: mango as a case study. J. Appl. Ecol. 49, 1373-1383.

Catford, J.A., Bode, M., Tilman, D., 2018. Introduced species that overcome life history tradeoffs can cause native extinctions. Nat. Commun. 9, 1-7.

Centrella, M.L., 2019. Regional and Local Drivers of Mason Bee (Genus Osmia) Decline Across the Eastern Seaboard. PhD Dissertation. Cornell University, USA.

Chacoff, N.P., Aizen, M.A., 2006. Edge effects on flower-visiting insects in grapefruit plantations bordering premontane subtropical forest. J. Appl. Ecol. 43, 18-27.

Chalcoff, V.R., Aizen, M.A., Ezcurra, C., 2012. Erosion of a pollination mutualism along an environmental gradient in a south Andean treelet, Embothrium coccineum (Proteaceae). Oikos 121, 471-480.

Chiari, W.C., De Toledo, V.D.A.A., Ruvolo-Takasusuki, M.C.C., Attencia, V.M., Costa, F.M., Kotaka, C.S., Sakaguti, E.S., Magalhães, H.R., 2005. Floral biology and behavior of Africanized honeybees Apis mellifera in soybean (Glycine max L. Merril). Braz. Arch. Biol. Technol. 48, 367-378.

Chittka, L., Spaethe, J., 2007. Visual search and the importance of time in complex decision making by bees. Arthropod Plant Interact. 1, 37-44.

Chuang, A., Peterson, C.R., 2016. Expanding population edges: theories, traits, and tradeoffs. Glob. Chang. Biol. 22, 494-512.

Crane, E., Graham, A.J., 1985. Bee hives of the ancient world. 1. Bee World 66, 23-41.

Dainese, M., Martin, E.A., Aizen, M.A., Albrecht, M., Bartomeus, I., Bommarco, R., Carvalheiro, L.G., Chaplin-Kramer, R., Gagic, V., Garibaldi, L.A., Ghazoul, J., Grab, H., Jonsson, M., Karp, D.S., Kennedy, C.M., Kleijn, D., Kremen, C., Landis, D.A., Letourneau, D.K., Marini, L., Poveda, K., Rader, R., Smith, H.G., Tscharntke, T., Andersson, G.K.S., Badenhausser, I., Baensch, S., Bezerra, A.D.M., Bianchi, F.J.J.A., Boreux, V., Bretagnolle, V., Caballero-Lopez, B., Cavigliasso, P., Ćetković, A., Chacoff, N.P., Classen, A., Cusser, S., Da Silva, E., Silva, F.D., Arjen De Groot, G., Dudenhöffer, J.H., Ekroos, J., Fijen, T., Franck, P., Freitas, B.M., Garratt, M.P.D., Gratton, C., Hipólito, J., Holzschuh, A., Hunt, L., Iverson, A.L., Jha, S., Keasar, T., Kim, T.N., Kishinevsky, M., Klatt, B.K., Klein, A.M., Krewenka, K.M., Krishnan, S., Larsen, A.E., Lavigne, C., Liere, H., Maas, B., Mallinger, R.E., Pachon, E.M., Martínez-Salinas, A., Meehan, T.D., Mitchell, M.G.E., Molina, G.A.R., Nesper, M., Nilsson, L., O'Rourke, M.E., Peters, M.K., Plećaš, M., Potts, S.G., de Ramos, D.L., Rosenheim, J.A., Rundlöf, M., Rusch, A., Sáez, A., Scheper, J., Schleuning, M., Schmack, J.M., 
Sciligo, A.R., Seymour, C., Stanley, D.A., Stewart, R., Stout, J.C., Sutter, L., Takada, M.B., Taki, H., Tamburini, G., Tschumi, M., Viana, B.F., Westphal, C., Willcox, B.K., Wratten, S.D., Yoshioka, A., Zaragoza-Trello, C., Zhang, W., Zou, Y., Steffan-Dewenter, I., 2019. A global synthesis reveals biodiversity-mediated benefits for crop production. Sci. Adv. 5, eaax0121.

Davis, M.A., 2009. Invasion Biology. Oxford University Press, Oxford, UK.

Dawson, W., Fischer, M., Van Kleunen, M., 2011. The maximum relative growth rate of common UK plant species is positively associated with their global invasiveness. Glob. Ecol. Biogeogr. 20, 299-306.

de Souza Rosa, A., Blochtein, B., Lima, D.K., 2011. Honey bee contribution to canola pollination in Southern Brazil. Sci. Agric. 68, 255-259.

Deguines, N., Jono, C., Baude, M., Henry, M., Julliard, R., Fontaine, C., 2014. Large-scale trade-off between agricultural intensification and crop pollination services. Front. Ecol. Environ. 12, 212-217.

Dicks, L.V., Viana, B., Bommarco, R., Brosi, B., Arizmendi, M.D.C., Cunningham, S.A., Galetto, L., Hill, R., Lopes, A.V., Pires, C., Taki, H., Potts, S.G., 2016. Ten policies for pollinators. Science 354, 975-976.

Dohzono, I., Yokoyama, J., 2010. Impacts of alien bees on native plant-pollinator relationships: a review with special emphasis on plant reproduction. Appl. Entomol. Zool. 45, 37-47.

Dukas, R., Morse, D.H., 2003. Crab spiders affect flower visitation by bees. Oikos $10,157-163$.

Elie, Y., 2015. Abeilles noires et ruches troncs. Causses et Cévennes 23, 163-174.

Engel, M.S., 1999. The taxonomy of recent and fossil honey bees (Hymenoptera Apidae; Apis). J. Hymenopt. Res. 8, 185-196.

Estay, P., 2007. Bombus en Chile: Especies, Biología y Manejo. Instituto Nacional de Investigaciones Agropecuarias (INIA), Ministerio de Agricultura, Santiago, Chile.

Faichnie et al., this issue. Scales matter: Maximising the effectiveness of interventions for pollinators and pollination. Advances in Ecological Research.

Fürst, M.A., McMahon, D.P., Osborne, J.L., Paxton, R.J., Brown, M.J.F., 2014. Disease associations between honeybees and bumblebees as a threat to wild pollinators. Nature 506, 364-366.

Garibaldi, L.A., Aizen, M.A., Klein, A.M., Cunningham, S.A., Harder, L.D., 2011a. Global growth and stability of agricultural yield decrease with pollinator dependence. Proc. Natl. Acad. Sci. U. S. A. 108, 5909-5914.

Garibaldi, L.A., Steffan-Dewenter, I., Kremen, C., Morales, J.M., Bommarco, R., Cunningham, S.A., Carvalheiro, L.G., Chacoff, N.P., Dudenhöffer, J.H., Greenleaf, S.S., Holzschuh, A., Isaacs, R., Krewenka, K., Mandelik, Y., Mayfield, M.M., Morandin, L.A., Potts, S.G., Ricketts, T.H., Szentgyörgyi, H., Viana, B.F., Westphal, C., Winfree, R., Klein, A.M., 2011b. Stability of pollination services decreases with isolation from natural areas despite honey bee visits. Ecol. Lett. 14, 1062-1072.

Garibaldi, L.A., Steffan-Dewenter, I., Winfree, R., Aizen, M.A., Bommarco, R., Cunningham, S.A., Kremen, C., Carvalheiro, L.G., Harder, L.D., Afik, O., Bartomeus, I., Benjamin, F., Boreux, V., Cariveau, D., Chacoff, N.P., Dudenhöffer, J.H., Freitas, B.M., Ghazoul, J., Greenleaf, S., Hipólito, J., Holzschuh, A., Howlett, B., Isaacs, R., Javorek, S.K., Kennedy, C.M., Krewenka, K.M., Krishnan, S., Mandelik, Y., Mayfield, M.M., Motzke, I., Munyuli, T., Nault, B.A., Otieno, M., Petersen, J., Pisanty, G., Potts, S.G., Rader, R., Ricketts, T.H., Rundlöf, M., Seymour, C.L., Schüepp, C., Szentgyörgyi, H., Taki, H., Tscharntke, T., Vergara, C.H., Viana, B.F., Wanger, T.C., Westphal, C., Williams, N., Klein, A.M., 2013. Wild pollinators enhance fruit set of crops regardless of honey bee abundance. Science 339, 1608-1611. 
Garibaldi, L.A., Carvalheiro, L.G., Leonhardt, S.D., Aizen, M.A., Blaauw, B.R., Isaacs, R., Kuhlmann, M., Kleijn, D., Klein, A.M., Kremen, C., Morandin, L., Scheper, J., Winfree, R., 2014. From research to action: enhancing crop yield through wild pollinators. Front. Ecol. Environ. 12, 439-447.

Garibaldi, L.A., Bartomeus, I., Bommarco, R., Klein, A.M., Cunningham, S.A., Aizen, M.A., Boreux, V., Garratt, M.P.D., Carvalheiro, L.G., Kremen, C., Morales, C.L., Schüepp, C., Chacoff, N.P., Freitas, B.M., Gagic, V., Holzschuh, A., Klatt, B.K., Krewenka, K.M., Krishnan, S., Mayfield, M.M., Motzke, I., Otieno, M., Petersen, J., Potts, S.G., Ricketts, T.H., Rundlöf, M., Sciligo, A., Sinu, P.A., Steffan-Dewenter, I., Taki, H., Tscharntke, T., Vergara, C.H., Viana, B.F., Woyciechowski, M., 2015. Trait matching of flower visitors and crops predicts fruit set better than trait diversity. J. Appl. Ecol. 52, 1436-1444.

Garibaldi, L.A., Pérez-Méndez, N., Garratt, M.P.D., Gemmill-Herren, B., Miguez, F.E., Dicks, L.V., 2019. Policies for ecological intensification of crop production. Trends Ecol. Evol. 34, 282-286.

Garibaldi, L.A., Sáez, A., Aizen, M.A., Fijen, T., Bartomeus, I., 2020. Crop pollination management needs flower visitor monitoring and target values. J. Appl. Ecol. 57, 664-670.

Geslin, B., Aizen, M.A., Garcia, N., Pereira, A.J., Vaissière, B.E., Garibaldi, L.A., 2017a. The impact of honey bee colony quality on crop yield and farmers' profit in apples and pears. Agric. Ecosyst. Environ. 248, 153-161.

Geslin, B., Gauzens, B., Baude, M., Dajoz, I., Fontaine, C., Henry, M., Ropars, L., Rollin, O., Thébault, E., Vereecken, N.J., 2017b. Massively introduced managed species and their consequences for plant-pollinator interactions. Adv. Ecol. Res. 57, 147-199.

Gibbs, J., Sheffield, C.S., 2009. Rapid range expansion of the wool-carder bee, Anthidium manicatum (Linnaeus) (Hymenoptera: Megachilidae), in North America. J. Kansas Entomol. Soc. 82, 21-29.

Goulson, D., 2003. Effects of introduced bees on native ecosystems. Annu. Rev. Ecol. Evol. Syst. 34, 1-26.

Goulson, D., 2010. Impacts of non-native bumblebees in Western Europe and North America. Appl. Entomol. Zool. 45, 7-12.

Goulson, D., Nicholls, E., Botías, C., Rotheray, E.L., 2015. Bee declines driven by combined stress from parasites, pesticides, and lack of flowers. Science 347, 1435-1444.

Greenleaf, S.S., Kremen, C., 2006. Wild bees enhance honey bees' pollination of hybrid sunflower. Proc. Natl. Acad. Sci. U. S. A. 103, 13890-13895.

Gross, C.L., MacKay, D., 1998. Honeybees reduce fitness in the pioneer shrub Melastoma affine (Melastomataceae). Biol. Conserv. 86, 169-178.

Guhl, A., 2008. Coffee production intensification and landscape change in Colombia, 1970-2002. In: Millington, A., Jepson, W. (Eds.), Land-Change Science in the Tropics: Changing Agricultural Landscapes. Springer, pp. 93-115.

Harder, L.D., Barrett, S.C.H., 1992. The energy cost of bee pollination for Pontederia cordata (Pontederiaceae). Funct. Ecol. 6, 226-233.

Harder, L.D., Johnson, S.D., 2005. Adaptive plasticity of floral display size in animalpollinated plants. Proc. R. Soc. B Biol. Sci. 272, 2651-2657.

Harder, L.D., Aizen, M.A., Richards, S.A., 2016a. The population ecology of male gametophytes: the link between pollination and seed production. Ecol. Lett. 19, 497-509.

Harder, L.D., Aizen, M.A., Richards, S.A., Joseph, M.A., Busch, J.W., 2016b. Diverse ecological relations of male gametophyte populations in stylar environments. Am. J. Bot. 103, 484-497.

Hargreaves, A.L., Harder, L.D., Johnson, S.D., 2009. Consumptive emasculation: the ecological and evolutionary consequences of pollen theft. Biol. Rev. 84, 259-276.

Hargreaves, A.L., Harder, L.D., Johnson, S.D., 2010. Native pollen thieves reduce the reproductive success of a hermaphroditic plant, Aloe maculata. Ecology 91, 1693-1703. 
Hastings, A., Cuddington, K., Davies, K.F., Dugaw, C.J., Elmendorf, S., Freestone, A., Harrison, S., Holland, M., Lambrinos, J., Malvadkar, U., Melbourne, B.A., Moore, K., Taylor, C., Thomson, D., 2005. The spatial spread of invasions: new developments in theory and evidence. Ecol. Lett. 8, 91-101.

Herrera, C.M., 1987. Components of pollinator "quality": comparative analysis of a diverse insect assemblage. Oikos 50, 79-90.

Herrera, C.M., 1989. Pollinator abundance, morphology, and flower visitation rate: analysis of the "quantity" component in a plant-pollinator system. Oecologia $80,241-248$.

Herrera, C.M., 2020. Gradual replacement of wild bees by honeybees in flowers of the Mediterranean Basin over the last 50 years. Proc. R. Soc. B 287, 20192657.

Herrera, C.M., Pozo, M.I., Medrano, M., 2013. Yeasts in nectar of an early-blooming herb: sought by bumble bees, detrimental to plant fecundity. Ecology 94, 273-279.

Hipólito, J., Nunes, D.O., Angel-Coca, C., Mahlmann, T., Galetto, L., Viana, B.F., 2020. Performance, effectiveness, and efficiency of honeybees as pollinators of Coffea arabica (Gentianales, Rubiaceae). Neotrop. Entomol. https://doi.org/10.1007/s13744-02000785-8

Hobbs, G.A., 1967. Obtaining and protecting red-clover pollinating species of Bombus (Hymenoptera: Apidae). Can. Entomol. 99, 943-951.

Holt, R.D., Bonsall, M.B., 2017. Apparent competition. Annu. Rev. Ecol. Evol. Syst. 48, 447-471.

Howlett, B.G., Donovan, B.J., 2010. A review of New Zealand's deliberately introduced bee fauna: current status and potential impacts. N. Z. Entomol. 33, 92-101.

Howlett et al., this issue. Using non-bee and bee pollinator-plant species interactions to design diverse plantings benefiting agri-ecosystems. Advances in Ecological Research.

Hung, K.L.J., Kingston, J.M., Albrecht, M., Holway, D.A., Kohn, J.R., 2018. The worldwide importance of honey bees as pollinators in natural habitats. Proc. R. Soc. B Biol. Sci. 285, 20172140.

IPBES, 2016. In: Potts, S.G., Imperatriz-Fonseca, V.L., Ngo, H.T. (Eds.), The Assessment Report of the Intergovernmental Science-Policy Platform on Biodiversity and Ecosystem Services on Pollinators, Pollination and Food Production. Secretariat of the Intergovernmental Science-Policy Platform on Biodiversity and Ecosystem Service, Bonn, Germany.

IPBES, 2019. Summary for Policymakers of the Thematic Assessment Report on Biodiversity and Ecosystem Services. Secretariat of the Intergovernmental SciencePolicy Platform on Biodiversity and Ecosystem Services, Bonn, Germany.

Irwin, R.E., Brody, A.K., 1998. Nectar robbing in Ipomopsis aggregata: effects on pollinator behavior and plant fitness. Oecologia 116, 519-527.

Irwin, R.E., Bronstein, J.L., Manson, J.S., Richardson, L., 2010. Nectar robbing: ecological and evolutionary perspectives. Annu. Rev. Ecol. Evol. Syst. 41, 271-292.

Jennersten, O., 1988. Insect dispersal of fungal disease: effects of Ustilago infection on pollinator attraction in Viscaria vulgaris. Oikos 51, 163-170.

Jeschke, J.M., Strayer, D.L., 2005. Invasion success of vertebrates in Europe and North America. Proc. Natl. Acad. Sci. U. S. A. 102, 7198-7202.

Johnson, S.D., Schiestl, F.P., 2016. Floral Mimicry. Oxford University Press, Oxford, UK. Kennedy, C.M., Lonsdorf, E., Neel, M.C., Williams, N.M., Ricketts, T.H., Winfree, R., Bommarco, R., Brittain, C., Burley, A.L., Cariveau, D., Carvalheiro, L.G., Chacoff, N.P., Cunningham, S.A., Danforth, B.N., Dudenhöffer, J.H., Elle, E., Gaines, H.R., Garibaldi, L.A., Gratton, C., Holzschuh, A., Isaacs, R., Javorek, S.K., Jha, S., Klein, A.M., Krewenka, K., Mandelik, Y., Mayfield, M.M., Morandin, L., Neame, L.A., Otieno, M., Park, M., Potts, S.G., Rundlöf, M., Saez, A., SteffanDewenter, I., Taki, H., Viana, B.F., Westphal, C., Wilson, J.K., Greenleaf, S.S., 
Kremen, C., 2013. A global quantitative synthesis of local and landscape effects on wild bee pollinators in agroecosystems. Ecol. Lett. 16, 584-599.

Kerr, J.T., Pindar, A., Galpern, P., Packer, L., Potts, S.G., Roberts, S.M., Rasmont, P., Schweiger, O., Colla, S.R., Richardson, L.L., Wagner, D.L., Gall, L.F., Sikes, D.S., Pantoja, A., 2015. Climate change impacts on bumblebees converge across continents. Science 349, 177-180.

Kleijn, D., Winfree, R., Bartomeus, I., Carvalheiro, L.G., Henry, M., Isaacs, R., Klein, A.M., Kremen, C., M'Gonigle, L.K., Rader, R., Ricketts, T.H., Williams, N.M., Lee Adamson, N., Ascher, J.S., Báldi, A., Batáry, P., Benjamin, F., Biesmeijer, J.C., Blitzer, E.J., Bommarco, R., Brand, M.R., Bretagnolle, V., Button, L., Cariveau, D.P., Chifflet, R., Colville, J.F., Danforth, B.N., Elle, E., Garratt, M.P.D., Herzog, F., Holzschuh, A., Howlett, B.G., Jauker, F., Jha, S., Knop, E., Krewenka, K.M., Le Féon, V., Mandelik, Y., May, E.A., Park, M.G., Pisanty, G., Reemer, M., Riedinger, V., Rollin, O., Rundlöf, M., Sardiñas, H.S., Scheper, J., Sciligo, A.R., Smith, H.G., Steffan-Dewenter, I., Thorp, R., Tscharntke, T., Verhulst, J., Viana, B.F., Vaissière, B.E., Veldtman, R., Westphal, C., Potts, S.G., 2015. Delivery of crop pollination services is an insufficient argument for wild pollinator conservation. Nat. Commun. 6, 1-9.

Klein, A.-M., Vaissière, B.E., Cane, J.H., Steffan-Dewenter, I., Cunningham, S.A., Kremen, C., Tscharntke, T., 2007. Importance of pollinators in changing landscapes for world crops. Proc. R. Soc. B Biol. Sci. 274, 303-313.

Klinkhamer, P.G.L., de Jong, T., de Jong, T.J., de Jong, T., 1993. Attractiveness to pollinators: a plant's dilemma. Oikos 66, 180-184.

Kovács-Hostyánszki, A., Espíndola, A., Vanbergen, A.J., Settele, J., Kremen, C., Dicks, L.V., 2017. Ecological intensification to mitigate impacts of conventional intensive land use on pollinators and pollination. Ecol. Lett. 20, 673-689.

Lockwood, J.L., Cassey, P., Blackburn, T., 2005. The role of propagule pressure in explaining species invasions. Trends Ecol. Evol. 20, 223-228.

Lodge, D.M., 1993. Biological invasions: lessons for ecology. Trends Ecol. Evol. 8, 133-137.

Macfarlane, R.P., Gurr, L., 1995. Distribution of bumble bees in New Zealand. N. Z. Entomol. 18, 9-36.

Mallinger, R.E., Gaines-Day, H.R., Gratton, C., 2017. Do managed bees have negative effects on wild bees?: a systematic review of the literature. PLoS One 12, e0189268.

Mancini et al., this issue. Detecting landscape scale consequences of insecticide use on invertebrate communities. Advances in Ecological Research.

Meyerson, L.A., Mooney, H.A., 2007. Invasive alien species in an era of globalization. Front. Ecol. Environ. 5, 199-208.

Miller-Struttmann, N.E., Geib, J.C., Franklin, J.D., Kevan, P.G., Holdo, R.M., Ebert-May, D., Lynn, A.M., Kettenbach, J.A., Hedrick, E., Galen, C., 2015. Functional mismatch in a bumble bee pollination mutualism under climate change. Science 349, 1541-1544.

Montalva, J., Dudley, L., Arroyo, M.T.K., Retamales, H., Abrahamovich, A.H., 2011. Geographic distribution and associated flora of native and introduced bumble bees (Bombus spp.) in Chile. J. Apic. Res. 50, 11-21.

Morales, C.L., 2009. Pollination requirements of raspberry in SW Argentina. Preliminary results. Int. J. Plant Reprod. Biol. 1, 195-198.

Morales, C.L., Aizen, M.A., 2002. Does invasion of exotic plants promote invasion of exotic flower visitors? A case study from the temperate forests of the southern Andes. Biol. Invasions 4, 87-100.

Morales, C.L., Aizen, M.A., 2006. Invasive mutualisms and the structure of plant-pollinator interactions in the temperate forests of north-west Patagonia, Argentina. J. Ecol. 94, 171-180. 
Morales, C.L., Arbetman, M.P., Cameron, S.A., Aizen, M.A., 2013. Rapid ecological replacement of a native bumble bee by invasive species. Front. Ecol. Environ. 11, 529-534.

Morales, C.L., Sáez, A., Garibaldi, L.A., Aizen, M.A., 2017. Disruption of pollination services by invasive pollinator species. In: Vila, M., Hulme, P., Ruiz, G. (Eds.), Impact of Biological Invasions on Ecosystem Services. Springer, pp. 203-220.

Moritz, R.F.A., Härtel, S., Neumann, P., 2005. Global invasions of the western honeybee (Apis mellifera) and the consequences for biodiversity. Écoscience 12, 289-301.

Morris, W.F., Vazquez, D.P., Chacoff, N.P., 2010. Benefit and cost curves for typical pollination mutualisms. Ecology 91, 1276-1285.

Morse, R.A., Calderone, N.W., 2003. The value of honey bees as pollinators of U.S. crops in 2000. Bee World 128, 1-15.

Nathan, R., Schurr, F.M., Spiegel, O., Steinitz, O., Trakhtenbrot, A., Tsoar, A., 2008. Mechanisms of long-distance seed dispersal. Trends Ecol. Evol. 23, 638-647.

Ngo, H.T., Mojica, A.C., Packer, L., 2011. Coffee plant-pollinator interactions: a review. Can. J. Zool. 89, 647-660.

Nogales, M., Heleno, R., Traveset, A., Vargas, P., 2012. Evidence for overlooked mechanisms of long-distance seed dispersal to and between oceanic islands. New Phytol. 194, 313-317.

Norsworthy, J.K., Ward, S.M., Shaw, D.R., Llewellyn, R.S., Nichols, R.L., Webster, T.M., Bradley, K.W., Frisvold, G., Powles, S.B., Burgos, N.R., Witt, W.W., Barrett, M., 2012. Reducing the risks of herbicide resistance: best management practices and recommendations. Weed Sci. 60, 31-62.

Ollerton, J., Winfree, R., Tarrant, S., 2011. How many flowering plants are pollinated by animals? Oikos 120, 321-326.

Ordano, M., Ornelas, J.F., 2005. The cost of nectar replenishment in two epiphytic bromeliads. J. Trop. Ecol. 21, 541-547.

Owen, R., 2017. Role of human action in the spread of honey bee (Hymenoptera: Apidae) pathogens. J. Econ. Entomol. 110, 797-801.

Pitts-Singer, T.L., Cane, J.H., 2011. The alfalfa leafcutting bee, Megachile rotundata: the world's most intensively managed solitary bee. Annu. Rev. Entomol. 56, 221-237.

Potts, S.G., Biesmeijer, J.C., Kremen, C., 2010. Global pollinator declines: trends, impacts and drivers. Trends Ecol. Evol. 25, 345-353.

Potts, S.G., Imperatriz-Fonseca, V., Ngo, H.T., Aizen, M.A., Biesmeijer, J.C., Breeze, T.D., Dicks, L.V., Garibaldi, L.A., Hill, R., Settele, J., Vanbergen, A.J., 2016. Safeguarding pollinators and their values to human well-being. Nature 540, 220-229.

Pretty, J., 2018. Intensification for redesigned and sustainable agricultural systems. Science 362, eaav0294.

Pyke, G.H., 2016. Floral nectar: pollinator attraction or manipulation? Trends Ecol. Evol. 31, 339-341.

Pyšek, P., Richardson, D.M., 2006. The biogeography of naturalization in alien plants. J. Biogeogr. 33, 2040-2050.

Quintero, C., Morales, C.L., Aizen, M.A., 2010. Effects of anthropogenic habitat disturbance on local pollinator diversity and species turnover across a precipitation gradient. Biodivers. Conserv. 19, 257-274.

Rader, R., Bartomeus, I., Garibaldi, L.A., Garratt, M.P.D., Howlett, B.G., Winfree, R., Cunningham, S.A., Mayfield, M.M., Arthur, A.D., Andersson, G.K.S., Bommarco, R., Brittain, C., Carvalheiro, L.G., Chacoff, N.P., Entling, M.H., Foully, B., Freitas, B.M., Gemmill-Herren, B., Ghazoul, J., Griffin, S.R., Gross, C.L., Herbertsson, L., Herzog, F., Hipólito, J., Jaggar, S., Jauker, F., Klein, A.-M., Kleijn, D., Krishnan, S., Lemos, C.Q., Lindström, S.A.M., Mandelik, Y., 
Monteiro, V.M., Nelson, W., Nilsson, L., Pattemore, D.E., de Pereira, O.N., Pisanty, G., Potts, S.G., Reemer, M., Rundlöf, M., Sheffield, C.S., Scheper, J., Schüepp, C., Smith, H.G., Stanley, D.A., Stout, J.C., Szentgyörgyi, H., Taki, H., Vergara, C.H., Viana, B.F., Woyciechowski, M., 2016. Non-bee insects are important contributors to global crop pollination. Proc. Natl. Acad. Sci. U. S. A. 113, 146-151.

Reade, C., Thorp, R., Goka, K., Wasbauer, M., McKenna, M., 2015. Invisible compromises: global business, local ecosystems, and the commercial bumble bee trade. Organ. Environ. 28, 436-457.

Rollin, O., Garibaldi, L.A., 2019. Impacts of honeybee density on crop yield: a meta-analysis. J. Appl. Ecol. 56, 1152-1163.

Roubik, D.W., 2002. The value of bees to the coffee harvest. Nature 417, 708.

Rusch, A., Chaplin-Kramer, R., Gardiner, M.M., Hawro, V., Holland, J., Landis, D., Thies, C., Tscharntke, T., Weisser, W.W., Winqvist, C., Woltz, M., Bommarco, R., 2016. Agricultural landscape simplification reduces natural pest control: a quantitative synthesis. Agric. Ecosyst. Environ. 221, 198-204.

Russo, L., Debarros, N., Yang, S., Shea, K., Mortensen, D., 2013. Supporting crop pollinators with floral resources: network-based phenological matching. Ecol. Evol. 3, 3125-3140.

Ruttner, F., 1988. Biogeography and Taxonomy of Honeybees. Springer-Verlag.

Sáez, A., Sabatino, M., Aizen, M.A., 2012. Interactive effects of large- and small-scale sources of feral honey-bees for sunflower in the Argentine pampas. PLoS One 7, e30968.

Sáez, A., Morales, C.L., Ramos, L.Y., Aizen, M.A., 2014. Extremely frequent bee visits increase pollen deposition but reduce drupelet set in raspberry. J. Appl. Ecol. 51, 1603-1612.

Sáez, A., Morales, C.L., Garibaldi, L.A., Aizen, M.A., 2017. Invasive bumble bees reduce nectar availability for honey bees by robbing raspberry flower buds. Basic Appl. Ecol. 19, 1-10.

Sáez, A., Morales, J.M., Morales, C.L., Harder, L.D., Aizen, M.A., 2018. The costs and benefits of pollinator dependence: empirically based simulations predict raspberry fruit quality. Ecol. Appl. 28, 1215-1222.

Sakagami, S.F., 1976. Specific differences in the bionomic characters of bumblebees. A comparative review. J. Fac. Sci. Hokkaido Univ. Ser. VI, Zool. 20, 390-447.

Scheper, J., Reemer, M., Van Kats, R., Ozinga, W.A., Van Der Linden, G.T.J., Schaminée, J.H.J., Siepel, H., Kleijn, D., 2014. Museum specimens reveal loss of pollen host plants as key factor driving wild bee decline in the Netherlands. Proc. Natl. Acad. Sci. U. S. A. 111, 17552-17557.

Schiesari, L., Waichman, A., Brock, T., Adams, C., Grillitsch, B., 2013. Pesticide use and biodiversity conservation in the Amazonian agricultural frontier. Philos. Trans. R. Soc. B Biol. Sci. 368, 20120378.

Schlaepfer, D.R., Glättli, M., Fischer, M., van Kleunen, M., 2010. A multi-species experiment in their native range indicates pre-adaptation of invasive alien plant species. New Phytol. 185, 1087-1099.

Schmid-Hempel, P., Kacelnik, A., Houston, A.I., 1985. Honeybees maximize efficiency by not filling their crop. Behav. Ecol. Sociobiol. 17, 61-66.

Schneider, S.S., DeGrandi-Hoffman, G., Smith, D.R., 2004. The African honey bee: factors contributing to a successful biological invasion. Annu. Rev. Entomol. 49, 351-376.

Schweiger, O., Biesmeijer, J.C., Bommarco, R., Hickler, T., Hulme, P.E., Klotz, S., Kühn, I., Moora, M., Nielsen, A., Ohlemüller, R., Petanidou, T., Potts, S.G., Pyšek, P., Stout, J.C., Sykes, M.T., Tscheulin, T., Vilà, M., Walther, G.R., Westphal, C., Winter, M., Zobel, M., Settele, J., 2010. Multiple stressors on biotic interactions: how climate change and alien species interact to affect pollination. Biol. Rev. 85, 777-795. 
Shea, K., Chesson, P., 2002. Community ecology theory as a framework for biological invasions. Trends Ecol. Evol. 17, 170-176.

Shykoff, J.A., Bucheli, E., 1995. Pollinator visitation patterns, floral rewards and the probability of transmission of Microbotryum violaceum, a veneral disease of plants. J. Ecol. 83, 189-198.

Simberloff, D., 2009. The role of propagule pressure in biological invasions. Annu. Rev. Ecol. Evol. Syst. 40, 81-102.

Simpson, B.B., Neff, J.L., 1981. Floral rewards: alternatives to pollen and nectar. Ann. Mo. Bot. Gard. 68, 301-322.

Smith, D.R., 1991. African bees in the Americas: insights from biogeography and genetics. Trends Ecol. Evol. 6, 17-21.

Smith-Ramírez, C., Vieli, L., Barahona-Segovia, R.M., Montalva, J., Cianferoni, F., Ruz, L., Fontúrbel, F.E., Valdivia, C.E., Medel, R., Pauchard, A., Celis-Diez, J.L., Riesco, V., Monzón, V., Vivallo, F., Neira, M., 2018. Las razones de por qué Chile debe detener la importación del abejorro comercial Bombus terrestris (Linnaeus) y comenzar a controlarlo. Gayana 82, 118-127.

Soroye, P., Newbold, T., Kerr, J., 2020. Climate change contributes to widespread declines among bumble bees across continents. Science 87, 685-688.

Steffan-Dewenter, I., Münzenberg, U., Bürger, C., Thies, C., Tscharntke, T., 2002. Scale-dependent effects of landscape context on three pollinator guilds. Ecology $83,1421-1432$.

Stout, J.C., Morales, C.L., 2009. Ecological impacts of invasive alien species on bees. Apidologie 40, 388-409.

Stubbs, C.S., Drummond, F.A., Osgood, E.A., 1994. Osmia ribifloris biedermannii and Megachile rotundata (Hymenoptera: Megachilidae) introduced into the lowbush blueberry agroecosystem in Maine. J. Kansas Entomol. Soc. 67, 173-185.

Sutherland, W.J., Barnard, P., Broad, S., Clout, M., Connor, B., Côté, I.M., Dicks, L.V., Doran, H., Entwistle, A.C., Fleishman, E., Fox, M., Gaston, K.J., Gibbons, D.W., Jiang, Z., Keim, B., Lickorish, F.A., Markillie, P., Monk, K.A., Pearce-Higgins, J.W., Peck, L.S., Pretty, J., Spalding, M.D., Tonneijck, F.H., Wintle, B.C., Ockendon, N., 2017. A 2017 horizon scan of emerging issues for global conservation and biological diversity. Trends Ecol. Evol. 32, 31-40.

Tilman, D., Lehman, C., 2001. Human-caused environmental change: impacts on plant diversity and evolution. Proc. Natl. Acad. Sci. U. S. A. 98, 5433-5440.

Tomiolo, S., Ward, D., 2018. Species migrations and range shifts: a synthesis of causes and consequences. Perspect. Plant Ecol. Evol. Syst. 33, 62-77.

Traveset, A., Willson, M.F., Sabag, C., 1998. Effect of nectar-robbing birds on fruit set of Fuchsia magellanica in Tierra del Fuego: a disrupted mutualism. Funct. Ecol. $12,459-464$.

Vanbergen et al., 2020. Transformation of agricultural landscapes in the Anthropocene: Nature's contributions to people, agriculture and food security. Adv. Ecol. Res. 63, 193-253.

van Doorn, W.G., 1997. Effects of pollination on floral attraction and longevity. J. Exp. Bot. 48, 1615-1622.

Vanbergen, A.J., The Insect Pollinators Initiative, 2013. Threats to an ecosystem service: pressures on pollinators. Front. Ecol. Environ. 11, 251-259.

Vanbergen, A.J., Espíndola, A., Aizen, M.A., 2018. Risks to pollinators and pollination from invasive alien species. Nat. Ecol. Evol. 2, 16-25.

Vannette, R.L., Fukami, T., 2016. Nectar microbes can reduce secondary metabolites in nectar and alter effects on nectar consumption by pollinators. Ecology 97, 1410-1419.

Vannette, R.L., Gauthier, M.P.L., Fukami, T., 2013. Nectar bacteria, but not yeast, weaken a plant-pollinator mutualism. Proc. R. Soc. B Biol. Sci. 280, 1752. 
Velthius, H.W., van Doorn, A., 2006. A century of advances in bumblebee domestication and the economic and environmental aspects of its commercialization for pollination. Apidologie 37, 421-451.

Westcott, L., Nelson, D., 2001. Canola pollination: an update. Bee World 82, 115-129.

Westphal, C., Steffan-Dewenter, I., Tscharntke, T., 2003. Mass flowering crops enhance pollinator densities at a landscape scale. Ecol. Lett. 6, 961-965.

Wilfert, L., Long, G., Leggett, H.C., Schmid-Hempel, P., Butlin, R., Martin, S.J.M., Boots, M., 2016. Honeybee disease: deformed wing virus is a recent global epidemic in honeybees driven by Varroa mites. Science 351, 594-597.

Williams, P.H., 1998. An annotated checklist of bumble bees with an analysis of patterns of description (Hymenoptera: Apidae, Bombini). Bull. Nat. Hist. Museum Entomol. 67, 79-152.

Willmer, P., 2011. Pollination and Floral Ecology. Princeton University Press, Princeton.

Winfree, R., Griswold, T., Kremen, C., 2007. Effect of human disturbance on bee communities in a forested ecosystem. Conserv. Biol. 21, 213-223.

Winfree, R., Aguilar, R., Vazquez, D.P., LeBuhn, G., Aizen, M.A., 2009. A meta-analysis of bees' responses to anthropogenic disturbance. Ecology 90, 2068-2076.

Winfree, R., Reilly, J.R., Bartomeus, I., Cariveau, D.P., Williams, N.M., Gibbs, J., 2018. Species turnover promotes the importance of bee diversity for crop pollination at regional scales. Science 359, 791-793.

Yang, G., 2005. Harm of introducing the western honeybee Apis mellifera L. to the Chinese honeybee Apis cerana F. and its ecological impact. Acta Entomol. Sin. 48, 401-406.

Young, H.J., 1988. Differential importance of beetle species pollinating Dieffenbachia longispatha (Araceae). Ecology 69, 832-844.

Young, H.J., Young, T.P., 1992. Alternative outcomes of natural and experimental high pollen loads. Ecology 73, 639-647.

Zattara, E.E., Aizen, M.A., 2019. Global bee decline. BioRxiv. 869784. https://doi.org/ $10.1101 / 869784$. 